\title{
Mineral Resources of the Wah Wah Mountains Wilderness Study Area, Beaver and Millard Counties, Utah
}
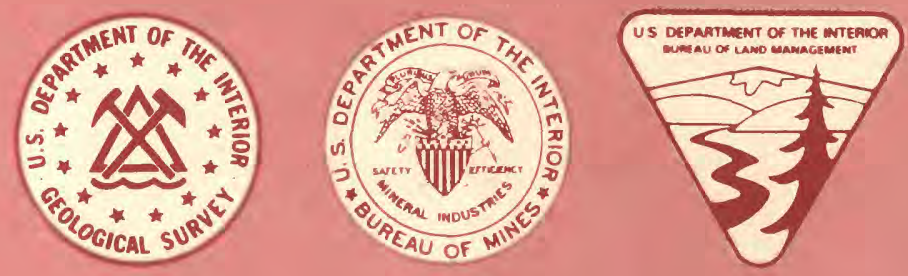

\section{U.S. GEOLOGICAL SURVEY BULLETIN 1749-B}

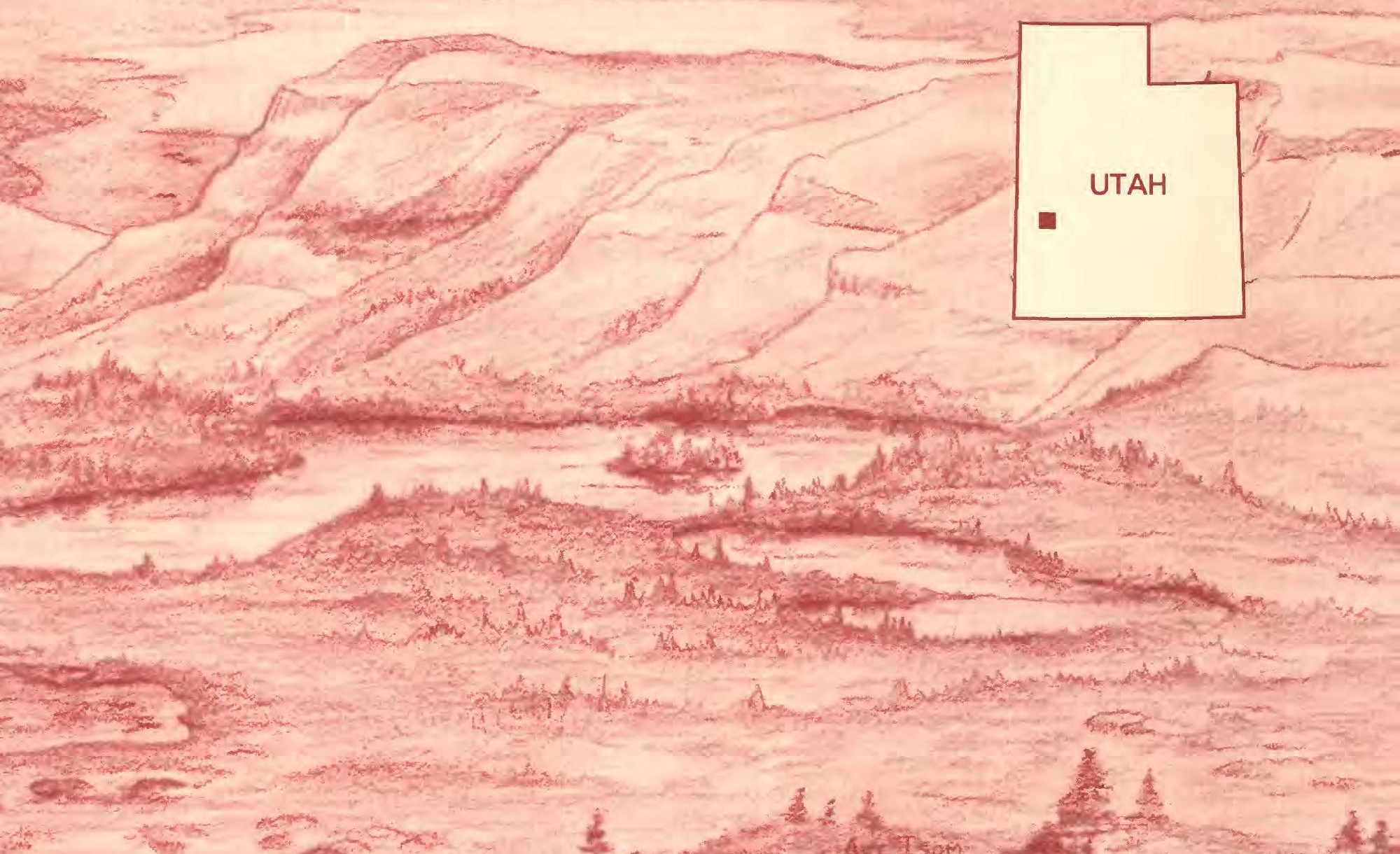



Chapter B

Mineral Resources of the

Wah Wah Mountains Wilderness Study Area, Beaver and Millard Counties, Utah

BY LESLIE J. COX, KAREN A. DUTTWWILER, DAVID L CAMPBELL, JOSEPH S. DUVAL, MELVIN H. PODWYSOCKI, VIKI BANKEY, and KENNETH L. COOK

U.S. Geological Survey

S. DON BROWN

U.S. Bureau of Mines

U.S. GEOLOGICAL SURVEY BULLETIN 1749

MINERAL RESOURCES OF WILDERNESS STUDY AREAS-WEST-CENTRAL UTAH 
DEPARTMENT OF THE INTERIOR

MANUEL LUJAN, JR., Secretary

\section{U.S. GEOLOGICAL SURVEY}

Dallas L. Peck, Director

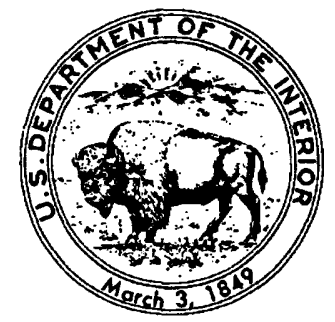

Any use of trade, product, or firm names in this publication is for descriptive

purposes only and does not imply endorsement by the U.S. Government.

For sale by the

Books and Open-File Reports Section

U.S. Geological Survey

Federal Center

Box 25425

Denver, CO 80225

\section{Library of Congress Cataloging-in-Publlcation Data}

Mineral resources of the Wah Wah Mountains Wilderness Study Area, Beaver and Millard counties, Utah / by Leslie J. Cox ... [et al.].

p. cm. - (Mineral resources of wilderness study areas - west-central

Utah ; ch. B) (U.S. Geological Survey bulletin ; 1749-B)

Bibliography: $p$.

Supt. of Docs. no.: I 19.3:1749-B

1. Mines and mineral resources-Utah-Wah Wah Mountains Wilderness.

2. Wah Wah Mountains Wilderness (Utah) I. Cox, Leslie J. II. Series.

III. Series: U.S. Geological Survey bulletin; 1749.

QE75.B9

no. 1749-B

[TN24.U8]

$557.3 \mathrm{~s}-\mathrm{dc} 19$

[553'.09792'46] 


\section{STUDIES RELATED TO WILDERNESS}

\section{Bureau of Land Management Wilderness Study Areas}

The Federal Land Policy and Management Act (Public Law 94-579, October 21, 1976) requires the U.S. Geological Survey and the U.S. Bureau of Mines to conduct mineral surveys on certain areas to determine the mineral values, if any, that may be present. Results must be made available to the public and be submitted to the President and the Congress. This report presents the results of a mineral survey of a part of the Wah Wah Mountains (UT-050-073/040-205) Wilderness Study Area, Beaver and Millard Counties, Utah. 



\section{CONTENTS}

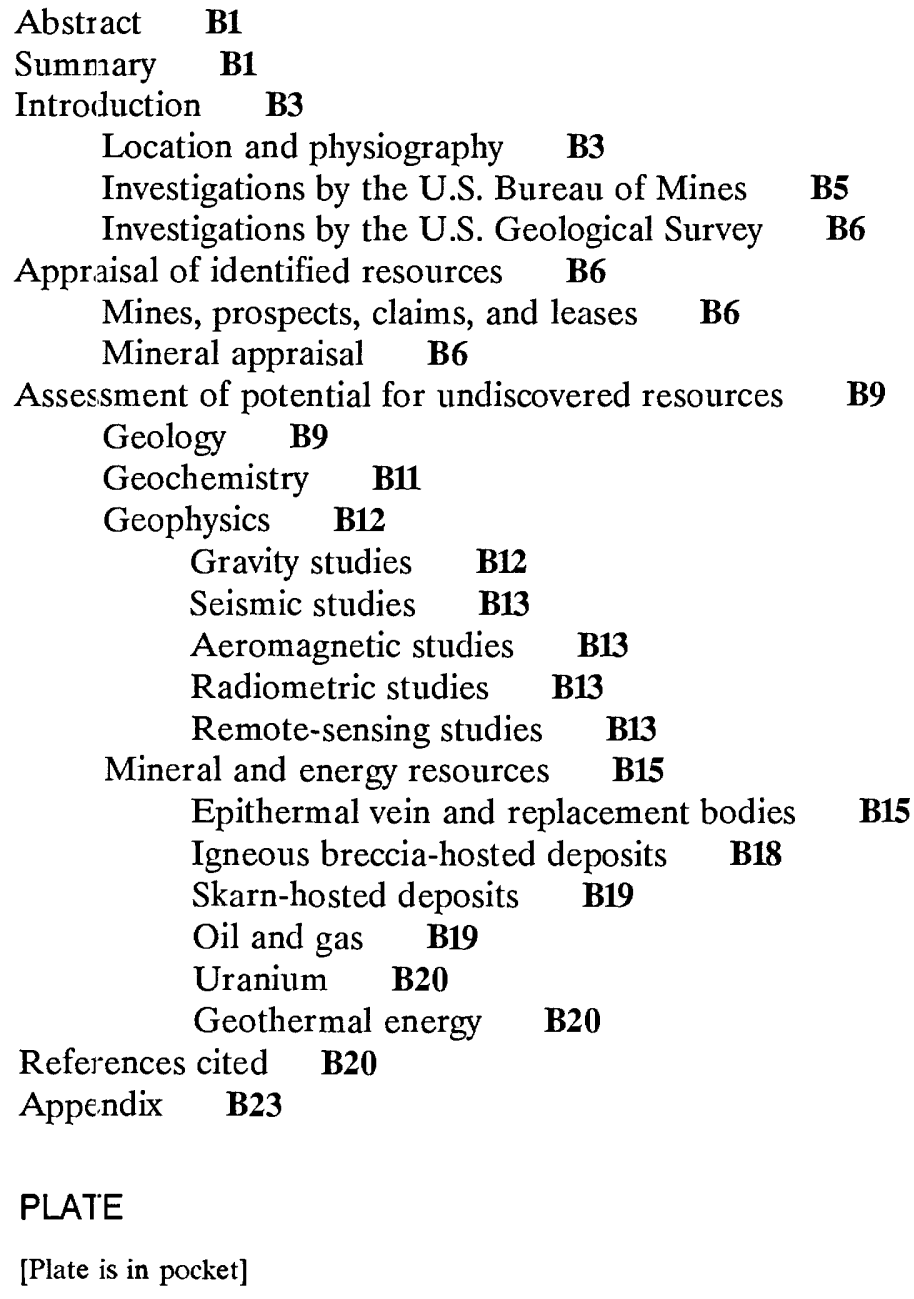

\section{PLATE}

[Plate is in pocket]

1. Map showing identified resources, mineral resource potential, geology, and sample localities of the Wah Wah Mountains Wilderness Study Area

\section{FIGURES}

1-5. Maps of the Wah Wah Mountains Wilderness Study Area showing:

1. Location $\mathbf{B 2}$

2. Mineral resource potential $\mathbf{B 4}$

3. Oil and gas leases and unpatented claims

4. Complete Bouguer gravity anomaly

B14

5. Aeromagnetic intensity

B16 


\section{TABLES}

1. Selected analytical data for U.S. Bureau of Mines samples from the Wah Wah Mountains Wilderness Study Area and vicinity

B7

2. Selected analytical data for U.S. Geological Survey samples from the Wah Wah Mountains Wilderness Study Area and vicinity B10

3. Range of detectable concentrations of selected trace elements in rock samples from the Wah Wah Mountains Wilderness Study Area B12

4. Summary of areas having spectral signatures characteristic of hydrothermally altered rock, determined from Landsat Thematic Mapper data, Wah Wah Mountains Wilderness Study Area B17 


\title{
Mineral Resources of the Wah Wah Mountains Wilderness Study Area, Beaver and Millard Counties, Utah
}

\author{
By Leslie J. Cox, Karen A. Duttweiler, David L. Campbell, Joseph S. Duval, \\ Melvin H. Podwysocki, Viki Bankey, and Kenneth L. Cook' \\ U.S. Geological Survey
}

S. Don Brown

U.S. Bureau of Mines

\section{ABSTRACT}

The Wah Wah Mountains Wilderness Study Area (UT-050-073/040-205) includes 36,382 acres in the northern part of the Wah Wah Mountains in western Utah. Identified resources in the Wah Wah Mountains Wilderness Study Area include two small iron occurrences on the southwestern boundary, consisting of less than 100 short tons of inferred subeconomic iron-rich material. The study area also has millions of cubic yards of inferred subeconomic resources of limestone and dolomite suitable for industrial and agricultural uses; of sandstone and quartzite suitable for container glass and industrial use; and of limestone, sandstone, and volcanic rock suitable for construction purposes. The wilderness study area has moderate energy resource potential for undiscovered oil and natural gas, and low energy resource potential for undisccivered uranium and geothermal energy. Several areas in the southern half of the wilderness study area have moderate mineral resource potential for undiscovered zinc, cadmium, and antimony, and moderate resource potential for associated molybdenum, lead, arsenic, bismuth, tungsten and gold in several types of vein and replacement bodies and in concealed igneous breccia deposits. The metal occurrences are attributed to episodes of epithermal (low-temperature) mineralization originating with Tertiary (see geologic time chart in Appendix) igneous activity. Some of the metals occur within an alteration zone around Tertiary intrusions. The rest of the study area has low

\footnotetext{
IUniversity of Utah.
}

Manuscript approved for publication November 23, 1988. resource potential for undiscovered zinc, cadmium, antimony, tungsten, molybdenum, lead, arsenic, bismuth, and gold.

\section{SUMMARY}

The Wah Wah Mountains Wilderness Study Area (UT050-073/040-205) is in the northern part of the Wah Wah Mountains in western Utah (fig. 1). At the request of the U.S. Bureau of Land Management, 36,382 acres of the wilderness study area were studied. Throughout this report the studied acreage is called either the "wilderness study area" or "study area." Field work was done during the fall of 1985 by the U.S. Bureau of Mines, and throughout the summer of 1986 by the U.S. Geological Survey and the U.S. Bureau of Mines, in order to appraise the mineral resources and assess the mineral resource potential of the study area.

The Wah Wah Mountains are an uplifted fault block of mostly early Paleozoic carbonate strata in the Basin and Range physiographic province. Small outcrops of volcanic rock, erupted in separate episodes of Tertiary volcanism, overlie carbonate strata in the northern and southern parts of the study area (fig. 2). At Wah Wah Summit (crossed by Utah State Highway 21, fig. 1), several Tertiary diorite stocks and rhyolitic intrusions and the altered area around them are exposed by erosion. The southern end of the study area lies at the western end of a broad, eastward-trending belt of stocks and voluminous volcanic rocks erupted in Tertiary time. East of the study area, these rocks contain epithermal mineral deposits, consisting predominantly of lead, zinc, and copper sulfides, as well as silver and gold. Quaternary alluvium covers the valleys adjacent to the Wah Wah Mountains and may conceal Tertiary sedimentary rocks. 


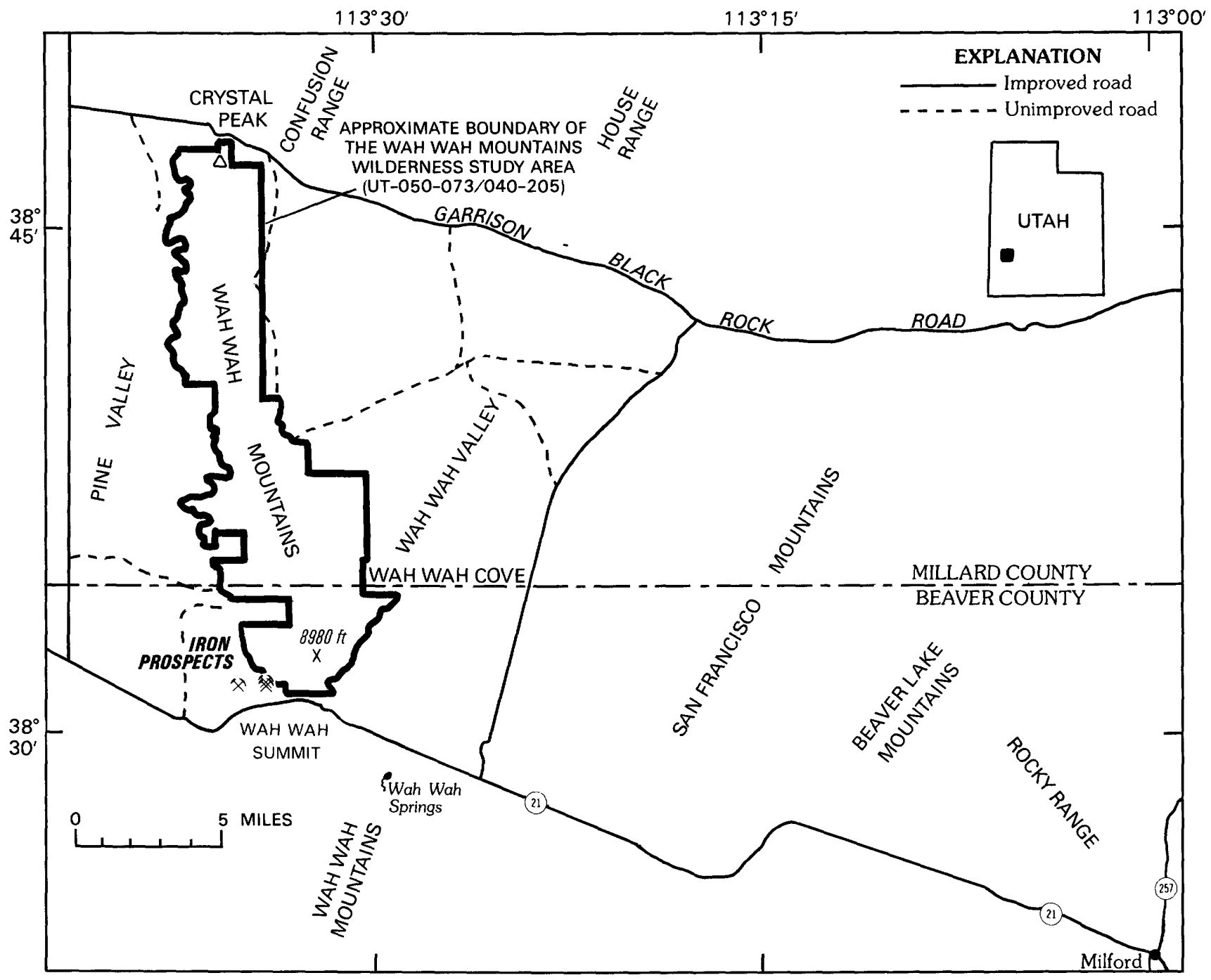

Figure 1. Index map showing the location of the Wah Wah Mountains Wilderness Study Area, Beaver and Millard Counties, Utah.

Topographic relief in the area is almost $3,400 \mathrm{ft}$ (feet); the highest elevation of $8,980 \mathrm{ft}$ is at the southern end of the study area.

Inferred subeconomic resources of common-variety limestone, dolomite, sandstone, quartzite, and volcanic rock are in the study area. Limestone, dolomite, and volcanic rock suitable for industrial uses are present throughout the study area. High-silica quartzite and sandstone suitable for container glass and other industrial uses are present in the north. Most of the rocks in the area are suitable for construction purposes; however, they are abundant at locations closer to population centers and markets. Two small iron prospects along the southwestern boundary of the study area (fig. 1) are within the contact-metamorphic aureole around intrusive rocks and are the only sites within the study area that have inferred subeconomic resources of iron-rich material.

In the Wah Wah Summit area, evidence of epithermal alteration is present as scattered areas of altered carbonate rock, small iron- and manganese-rich gossans (leached cappings), and skarn (rocks composed mostly of limebearing silicate minerals) zones adjacent to dioritic and rhyolitic intrusions. Several metals are associated with the epithermally altered rocks. High concentrations of zinc, cadmium, arsenic, bismuth, lead, antimony, and molybdenum are often associated with epithermally altered rocks. Similar zones are most likely present within the study area at depth (in Areas 1 and 2, fig. 2).

Areas 1 and 2 have moderate mineral resource potential for undiscovered zinc, cadmium, and related antimony, molybdenum, lead, arsenic, and bismuth within vein and replacement bodies in carbonate rocks closely associated with Tertiary intrusions. Area 2 also has moderate mineral resource potential for undiscovered gold in vein and replacement bodies in carbonate rocks.

Aeromagnetic data support the interpretation of the existence of a stock beneath the sedimentary rocks of Wah Wah Valley near the southeastern corner of the study area. Small dikes intrude volcanic rocks $1 \mathrm{mi}$ (mile) east of Area 2 (fig. 2) and may be surface expressions of the hidden stock 
or of the exposed stocks in the Wah Wah Summit area (fig. 2). This evidence supports the possibility of intrusive cupolas (tops) and associated breccia hidden beneath the sedimentary and volcanic rocks in the southeastern corner of the study area (Area 2, fig. 2). Sulfides of lead, antimony, and bismuth, as well as barite gangue, may be deposited interstitially within the breccia. Area 2 has moderate mineral resource potential for antimony, and moderate potential for resources of associated bismuth, arsenic, molybdenum, lead, zinc, cadmium, and gold in deposits within concealed igneous breccia.

The contact-metamorphic aureoles (zones of alteration) associated with the stocks in the Wah Wah Summit area extend as much as $1 \mathrm{mi}$ into the study area and may overlie unexposed stock(s) a short distance below the surface. The likely areas of skarn-type mineralization are where the igneous intrusions in the Wah Wah Summit area contact shaly and dolomitic limestones. Areas 1 and 2 (fig. 2) have moderate mineral resource potential for undiscovered zinc, lead, and tungsten in skarn deposits associated with subsurface extensions of the exposed intrusions in the Wah Wah Summit area (fig. 1).

Anomalous concentrations of antimony and barium were reported in samples collected from drainages in the Wah Wah Cove area (Areas 3 and 4, fig. 2). Scheelite was observed in panned-concentrate samples containing as much as 100 ppm (parts per million) tungsten (Area 4, fig. 2). Evidence of epithermal alteration was observed in the Wah Wah Cove area. Area 3 has moderate mineral resource potential for undiscovered antimony in epithermal vein and replacement bodies. Area 4 has moderate mineral resource potential for undiscovered antimony and tungsten resources in epithermal vein and replacement bodies in carbonate strata.

Areas outside of the Wah Wah Summit and Wah Wah Cove areas have low mineral resource potential for zinc, cadmium, antimony, tungsten, molybdenum, lead, arsenic, bismuth, and gold in several types of vein, replacement, and breccia deposits associated with Tertiary igneous activity.

The eastern part of the Basin and Range province contains favorable source rocks (Mississippian and Cretaceous) and structural traps (in lower Paleozoic and Late Proterozoic strata) for oil and gas. The study area lies within a zone identified as having a favorable thermal-maturation history for the source rocks. Favorable stratigraphy and structure in the subsurface are indicated by the geologic history and seismic evidence. However, oil and natural-gas exploration to date has been unsuccessful in identifying resources in the vicinity of the study area. Basin and Range province tectonism may have breached older structural traps. Oil and gas accumulations may have dissipated along basin-range faults. The sedimentary rocks underlying the Wah Wah Mountains Wilderness Study Area have moderate energy resource potential for undiscovered oil and natural gas.

Low gamma-ray levels and the absence of uranium geochemical anomalies indicate that the wilderness study area has low mineral resource potential for undiscovered near-surface uranium deposits.
The absence of thermal springs and the lack of large areas of thick, thermally insulating basin-fill deposits in the study area indicate that it has low potential for undiscovered geothermal energy resources.

\section{INTRODUCTION}

\section{Location and Physiography}

The Wah Wah Mountains Wilderness Study Area (UT-050-073/040-205) is in the western part of the Richfield $1^{\circ} \times 2^{\circ}$ quadrangle in Beaver and Millard Counties, Utah, about $20 \mathrm{mi}$ east of the Utah-Nevada border. The study area encompasses the northern part of the Wah Wah Mountains and parts of the adjacent valleys, which lie within the Basin and Range physiographic province, and it extends northward along the length of the range from Wah Wah Summit to the pass north of Crystal Peak (fig. 1). The Wah Wah Mountains are bounded by Pine Valley on the west and Wah Wah Valley to the east. The narrow, flat-topped range is rugged on all sides; the western edge is steep and cliffy. Relief in the study area is nearly $3,400 \mathrm{ft}$, and the highest elevation of $8,980 \mathrm{ft}$ is at the southern end. Vegetation changes with elevation and is typical of a semiarid to arid climate.

The study area is easily accessed by Utah State Highway 21, which crosses Wah Wah Summit about 0.3 mi from the southern boundary (fig. 1) and connects the nearest population centers, Milford, Utah, $24 \mathrm{mi}$ to the east and Garrison, Nev., $31 \mathrm{mi}$ to the west. Major access routes from all other directions are light-duty, allweather, improved-surface roads such as the GarrisonBlack Rock Road to the north. Unimproved dirt roads accessing all parts of the study area locally require four-wheel-drive vehicles for passage.

This report presents an evaluation of the mineral endowment (identified resources and mineral resource potential) of the wilderness study area and is the product of several separate studies by the U.S. Bureau of Mines and the U.S. Geological Survey. Identified resources are classified according to the system of the U.S. Bureau of Mines and U.S. Geological Survey (1980), which is shown in the Appendix of this report. Identified resources are studied by the USBM. Mineral resource potential is the likelihood of occurrence of undiscovered metals and nonmetals, industrial rocks and minerals, and of undiscovered energy sources (coal, oil, gas, oil shale, and geothermal sources). It is classified according to the system of Goudarzi (1984) and is shown in the Appendix. Undiscovered resources are studied by the USGS. 


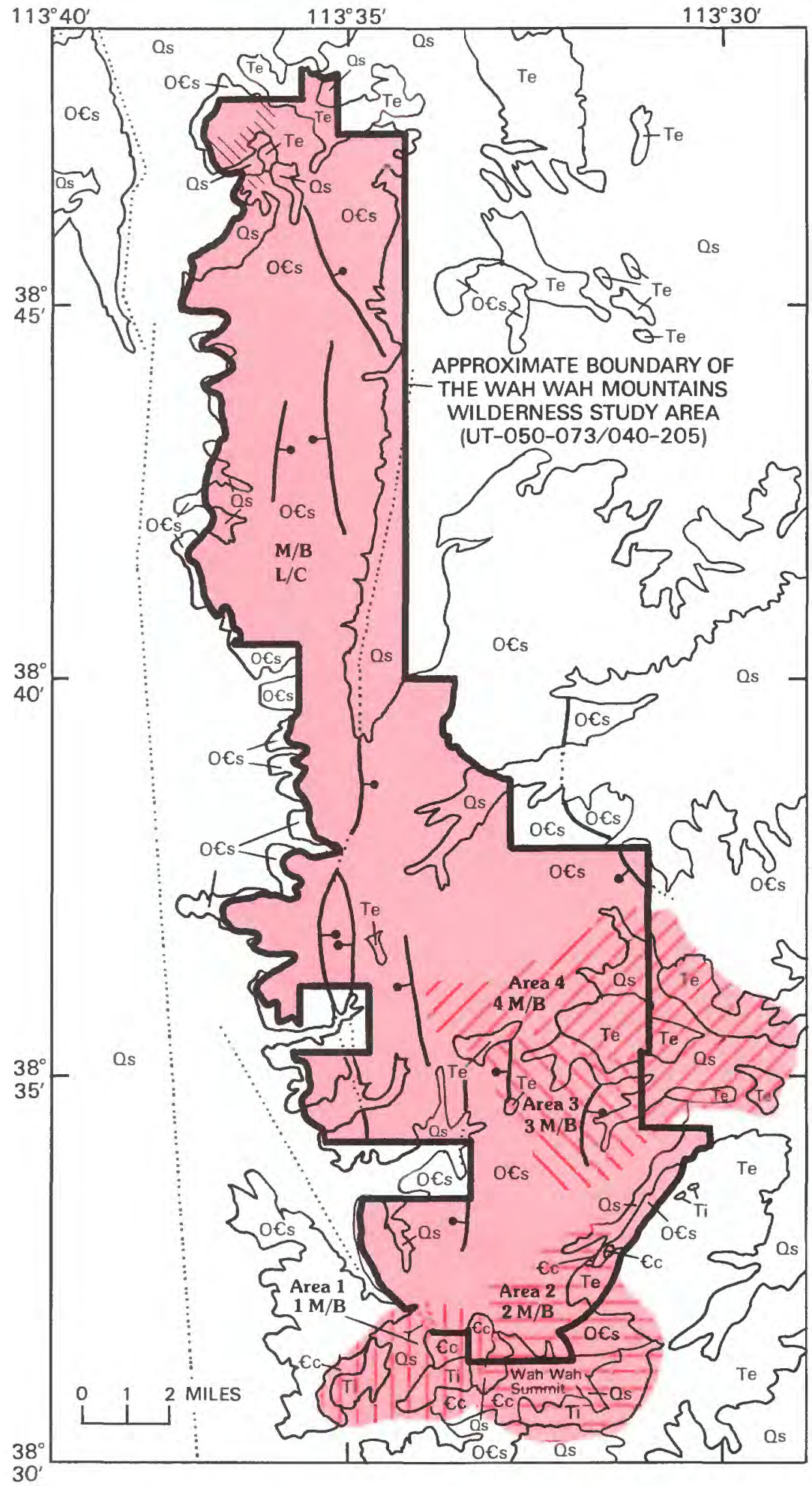

Figure 2 (above and facing page). Summary map showing identified resources and mineral resource potential of the Wah Wah Mountains Wilderness Study Area (UT-050-073/040-205), Beaver and Millard Counties, Utah. Geology simplified from Hintze, 1974a, b, and Hintze and others, 1984. 
EXPLANATION OF IDENTIFIED RESOURCES AND MINERAL RESOURCE POTENTIAL

[The entire study area has inferred subeconomic resources of limestone, dolomite, and volcanic rock. Numbered areas are described in text]

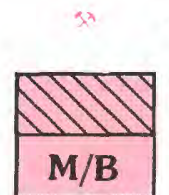

Geologic terrane having inferred subeconomic resources of iron

Geologic terrane having inferred subeconomic resources of silica in high-silica sandstone and quartzite

Geologic terrane having moderate energy resource potential for oil and gas, with certainty level B-Applies to entire study area

$1 \mathrm{M} / \mathrm{B}$ Geologic terrane having moderate mineral resource potential for zinc, cadmium, antimony, molybdenum, lead, arsenic, and bismuth in vein and replacement deposits, with certainty level B; and for zinc, lead, and tungsten in skarn, with certainty level B

Geologic terrane having moderate mineral resource potential for zinc, cadmium, antimony, molybdenum, lead, arsenic, bismuth and gold in vein and replacement deposits, or in igneous breccia, with certainty level B; and for zinc, lead and tungsten in skarn, with certainty level $\mathrm{B}$

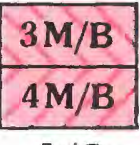

Geologic terrane having moderate mineral resource potential for antimony, with certainty level B

Geologic terrane having moderate mineral resource potential for antimony and tungsten, with certainty level B

$\mathrm{L} / \mathrm{C}$

Geologic terrane having low resource potential for uranium, geothermal energy, and all metals except as described above, with certainty level C-Applies to entire study area Certainty levels

B Available information suggests the level of mineral resource potential

C Available information gives a good indication of the level of mineral resource potential
CORRELATION OF MAP UNITS

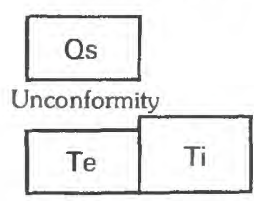

Unconformity

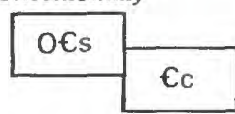

\} QUATERNARY

\} TERTIARY

$\left\{\begin{array}{l}\text { ORDOVICIAN } \\ \text { CAMBRIAN }\end{array}\right.$

\section{LIST OF MAP UNITS}

Os Surficial material (Quaternary)

Te Extrusive igneous rocks (Tertiary)

$\mathrm{Ti} \quad$ Intrusive igneous rocks (Tertiary)

OCs Sedimentary rocks (Ordovician and Cambrian)

€c Contact metamorphosed sedimentary rocks (Cambrian) Contact-Approximately located

9 Fault-Dotted where concealed; bar and ball on downthrown side

Summary of areas having mineral resource potential in and adjacent to the Wah Wah Mountains Wilderness Study Area [Level of potential/level of certainty explained below; commodities listed in order of relative importance]

\begin{tabular}{|c|c|c|c|c|}
\hline $\begin{array}{l}\text { Area name and number } \\
\text { (where applicable) }\end{array}$ & $\begin{array}{l}\text { Resource } \\
\text { potential }\end{array}$ & $\begin{array}{l}\text { Level of } \\
\text { potential/ } \\
\text { level of } \\
\text { certainty }\end{array}$ & Commodities & Type of deposit \\
\hline \multirow[t]{2}{*}{ Wah Wah Summit (west), 1} & Moderate & $\mathrm{M} / \mathrm{B}$ & $\begin{array}{l}\mathrm{Zn}, \mathrm{Cd}, \mathrm{Sb}, \mathrm{Mo}, \mathrm{Pb}, \mathrm{As} \text {, } \\
\mathrm{Bi} \text {. }\end{array}$ & $\begin{array}{l}\text { Vein and replacement in car- } \\
\text { bonate host rock. }\end{array}$ \\
\hline & Moderate & $M / B$ & $\mathrm{Zn}, \mathrm{Pb}, \mathrm{W} \ldots$ & Skarn. \\
\hline \multirow[t]{3}{*}{ Wah Wah Summit (east), 2} & Moderate & $\mathrm{M} / \mathrm{B}$ & $\begin{array}{l}\mathrm{Zn}, \mathrm{Cd}, \mathrm{Sb}, \mathrm{Mo}, \mathrm{Pb}, \mathrm{As}, \\
\mathrm{Bi}, \mathrm{Au} .\end{array}$ & $\begin{array}{l}\text { Vein and replacement in car- } \\
\text { bonate host rock. }\end{array}$ \\
\hline & Moderate & $\mathrm{M} / \mathrm{B}$ & $\mathrm{Pb}, \mathrm{Sb}, \mathrm{Bi}, \mathrm{As}, \mathrm{Mo}$ & Igneous breccia host. \\
\hline & Moderate & $\mathrm{M} / \mathrm{B}$ & $\mathrm{Zn}, \mathrm{Pb}, \mathrm{W}$ & Skarn. \\
\hline Wah Wah Cove (south), 3 & Moderate & $\mathrm{M} / \mathrm{B}$ & 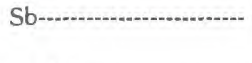 & $\begin{array}{l}\text { Vein and replacement in car- } \\
\text { bonate or volcanic host rock. }\end{array}$ \\
\hline Wah Wah Cove, 4 & Moderate & $M / B$ & $\mathrm{Sb}, \mathrm{W}$ & $\begin{array}{l}\text { Vein and replacement in car- } \\
\text { bonate or volcanic host rock. }\end{array}$ \\
\hline $\begin{array}{l}\text { Study area outside of areas } \\
1-4 \text {. }\end{array}$ & Low........ & L/C & $\begin{array}{l}\mathrm{Zn}, \mathrm{Cd}, \mathrm{Sb}, \mathrm{W}, \mathrm{Mo}, \mathrm{Pb}, \\
\mathrm{As}, \mathrm{Bi}, \mathrm{Au} .\end{array}$ & \\
\hline Entire study area & Moderate & $\mathrm{M} / \mathrm{B}$ & Oil and gas-............. & Subsurface sedimentary rocks. \\
\hline Entire study area & Low....... & $\mathrm{L} / \mathrm{C}$ & Geothermal resources & \\
\hline Entire study area & Low-.....- & $\mathrm{L} / \mathrm{C}$ & Uranium & \\
\hline
\end{tabular}

\section{Investigations by the U.S. Bureau of Mines}

U.S. Bureau of Mines personnel conducted a comprehensive literature search and a field investigation of minerals and mining activity in and near the study area. Mining-claim and oil and gas lease records obtained from the Utah State office of the U.S. Bureau of Land Management were examined to determine the type of mining and prospecting activity conducted in the area as of May 1985 (for mining claims) and April 1986 (for oil and gas leasing). A field investigation by ground and 
helicopter reconnaissance was conducted in search of mines, prospects, claims, and mineralized zones. Fourteen rock samples with visible or suspected ore minerals were analyzed for gold by fire assay plus atomicabsorption techniques and for silver by atomic absorption. Various methods of analyses were employed for the detection of antimony, arsenic, cobalt, copper, iron, lead, mercury, molybdenum, thallium, tungsten, and zinc in selected rock samples. The direct current plasma method of analysis was performed on 16 samples of limestone and 1 each of sandstone and quartzite to determine their suitability for chemical, metallurgical, and agricultural use. A comprehensive summary of the results of the U.S. Bureau of Mines work in the wilderness study area is in Brown (1987).

\section{Investigations by the U.S. Geological Survey}

The U.S. Geological Survey conducted field investigations in the study area in 1986 . Field work by L.J. Cox and K.S. Panter included collecting 137 rock and 22 soil samples for geochemical analysis (Adrian, Hageman, and others, 1988) and field checking of existing geologic maps. The geochemical survey carried out by K.A. Duttweiler and J.D. Gaccetta included collecting 49 stream-sediment and heavy-mineral-concentrate samples and 181 rock samples (Adrian, Gaccetta, and others, 1988). Aeromagnetic and radiometric data were collected by the U.S. Geological Survey in 1972 along north-south flight lines nominally spaced $2 \mathrm{mi}$ apart. These data were interpreted for the study area by D.L. Campbell and J.S. Duval, respectively. Gravity data compiled in $1986-87$ by K.L. Cook and Viki Bankey were interpreted by D.L. Campbell. Digital remote-sensing data from the Landsat Thematic Mapper instrument were processed, and the images were examined by M.H. Podwysocki for colors interpreted to correspond with areas of altered rock.

Detailed geologic maps of the study area at scale 1:62,500 (Hintze, 1974a, b; Hintze and others, 1984) were used extensively during the course of the study, and a simplified version of these maps appears on plate 1 and figure 2. Large-scale maps accompanying topical studies of selected igneous bodies within the study area made by Dunn (1959) for the Crystal Peak area and Erickson (1966) for the Wah Wah Summit area were also utilized.

Other resource-assessment studies of the entire Richfield $1^{\circ} \times 2^{\circ}$ quadrangle have recently been published by Huntsman (1981) for the U.S. Department of Energy National Uranium Resource Evaluation program and by Steven and Morris $(1984,1987)$ under the auspices of the U.S. Geological Survey Conterminous United States Mineral Assessment Program.

\section{APPRAISAL OF IDENTIFIED RESOURCES}

\section{By S. Don Brown \\ U.S. Bureau of Mines}

\section{Mines, Prospects, Claims, and Leases}

There are no patented mining claims within the Wah Wah Mountains Wilderness Study Area, but there are 46 unpatented claims (fig. 3). The only known evidence of mining activity inside the study area is along the southern boundary in Area 1 where two small iron occurrences are exposed in a short adit (in loc. 37-40, pl. 1) and in a small prospect pit (loc. 41, pl. 1). Several additional prospects are in the same area, outside the study-area boundary (locs. 34, 35, 36, 44, and 45, pl. 1). The size of the workings indicates that any past production was small. Two small agate prospects are about $1 \frac{1}{2}$ mi outside the eastern boundary in Area 4 .

About half of the study area (33 square miles) is leased for oil and gas (fig. 3).

\section{Mineral Appraisal}

The two small iron occurrences along the boundary of the study area have been explored by a short adit and a small prospect pit. The adit was driven in a northtrending fault zone of clayey gouge, at least $5 \mathrm{ft}$ thick, evident for about $40 \mathrm{ft}$ along strike. The major iron mineral is hematite, which occurs as hard chunks irregularly distributed throughout the gouge zone. The country rocks are altered limestone and marble near a contact with rhyolite. Minor amounts of other metals occur with the hematite including zinc, copper, manganese, molybdenum, and lead (table 1, samples 37-41). Similar iron occurrences outside of the study area are about $0.5 \mathrm{mi}$ west of the adit. Bullock (1970, p. $13,14)$ referred to all the iron occurrences in this area as the Wah Wah Pass iron deposits and credits the iron-ore resources of this area with fewer than 500 tons of hematite. Less than 100 tons of iron-rich material is present at the adit (loc. 37-40, pl. 1) in the study area. Less than 100 tons of inferred subeconomic iron resources are indicated in the study area.

Diorite stocks crop out just outside the southern end of the study area at Wah Wah Summit and were shown by Hintze (1974b) to extend underneath the study area. The limestone has been metamorphosed near the contact with the intrusions, and impure marble is the most common altered rock. Skarn zones occur locally and have been prospected. Assays of samples from the prospect pits (table 1, samples 34-36) reveal very low metal values. There are no ore deposits in this area at the surface. 
Table 1. Selected data for samples collected by the U.S. Bureau of Mines from prospects, skarn, and altered rock within and near the Wah Wah Mountains Wilderness Study Area, Utah

[ppm, parts per million; ppb, parts per billion. All samples assayed for $\mathrm{Ag}$ and $\mathrm{Au}$ but none was detected at detection limits of $0.2 \mathrm{ppm}$ for $\mathrm{Ag}$ by the atomic-absorption method and $5 \mathrm{ppb}$ for Au by fire assay and atomic-absorption methods. Types of analyses include colorimetry for As and $\mathrm{W}$, cold-vapor atomic absorption for $\mathrm{Hg}$, direct current plasma for $\mathrm{Cu}, \mathrm{Pb}, \mathrm{Mo}$, and $\mathrm{Zn}$, and an emission spectrographic method for $\mathrm{Mn}$. Analyses by U.S. Bureau of Mines Reno Research Center and Bondar-Clegg, Inc. Sample localities shown on pl. 1]

\begin{tabular}{|c|c|c|}
\hline Sample No. & Location and description & Element and (concentrations) \\
\hline \multicolumn{3}{|c|}{ Area 2. Altered 1imestone } \\
\hline 24 & $\begin{array}{l}\text { Brecciated chert lenses in crystallized limestone, } \\
\text { near contact with andesite. }\end{array}$ & $\mathrm{As}(4 \mathrm{ppm}) ; \mathrm{Hg}(25 \mathrm{ppb})$ \\
\hline 28 & $\begin{array}{l}\text { Altered and crystallized limestone, bright-red } \\
\text { iron oxide crusts; breccia gouge, some bleaching. }\end{array}$ & As (5 ppm); Hg(30 ppb) \\
\hline 29 & Similar to sample 28 . & $\mathrm{Hg}(30 \mathrm{ppb})$ \\
\hline \multicolumn{3}{|c|}{ Area 1. Skarn } \\
\hline 34 & Bulldozer cut $30 \mathrm{ft}$ long. & $\mathrm{W}(3 \mathrm{ppm})$ \\
\hline 35 & $\begin{array}{l}\text { Trench } 100 \mathrm{ft} \text { long; near contact between limestone } \\
\text { and diorite; calcite, silicified diorite, } \\
\text { andradite garnet, idocrase. }\end{array}$ & $\mathrm{W}(2 \mathrm{ppm})$ \\
\hline 36 & Shallow bulldozer scrape; rock similar to sample 35. & $\mathrm{~W}(2 \mathrm{ppm})$ \\
\hline \multicolumn{3}{|c|}{ Area 1. Iron prospects } \\
\hline 37 & $\begin{array}{l}\text { Adit, } 30 \mathrm{ft} \text { long; winze, } 15 \mathrm{ft} \text { deep; sample from } \\
\text { portal; thick zone of brecciated, white, clayey } \\
\text { gouge; heavily stained with iron oxides; near } \\
\text { contact between rhyolite and altered limestone. }\end{array}$ & $\begin{array}{l}\mathrm{Cu}(19 \mathrm{ppm}), \mathrm{Pb}(16 \mathrm{ppm}) \\
\mathrm{Zn}(265 \mathrm{ppm}), \operatorname{Mo}(16 \mathrm{ppm}) \\
\operatorname{Mn}(24 \mathrm{ppm})\end{array}$ \\
\hline 38 & $\begin{array}{l}\text { From adit of sample } 37,15 \mathrm{ft} \text { inside; rock similar } \\
\text { to sample } 37 \text {. }\end{array}$ & $\begin{array}{l}\mathrm{Cu}(19 \mathrm{ppm}), \mathrm{Pb}(6 \mathrm{ppm}), \mathrm{Zn}(232 \mathrm{ppm}) \\
\quad \mathrm{Mo}(12 \mathrm{ppm}), \mathrm{W}(2 \mathrm{ppm}), \operatorname{Mn}(80 \mathrm{ppm}) .\end{array}$ \\
\hline 39 & $\begin{array}{l}\text { From locality of sample } 37 \text {, open cut, adjacent to } \\
\text { portal; limestone brecciated, altered, and } \\
\text { crystallized; limonitic gouge in fractures; } \\
\text { near contact with gouge zone. }\end{array}$ & $\begin{array}{l}\mathrm{Cu}(7 \mathrm{ppm}), \mathrm{Zn}(227 \mathrm{ppm}), \operatorname{Mo}(5 \mathrm{ppm}) \\
\quad \operatorname{Mn}(9,500 \mathrm{ppm})\end{array}$ \\
\hline 40 & $\begin{array}{l}\text { Dump, from adit of sample } 37 \text {; abundant hematite; } \\
\text { intense iron oxide staining. }\end{array}$ & $\begin{array}{l}\mathrm{Cu}(46 \mathrm{ppm}), \operatorname{Zn}(1,443 \mathrm{ppm}) \\
\quad \operatorname{Mo}(30 \mathrm{ppm}), \operatorname{Mn}(716 \mathrm{ppm})\end{array}$ \\
\hline 41 & $\begin{array}{l}\text { Smal1 stockpile of altered rhyolite from prospect } \\
\text { pit; small rhyolite outcrop within limestone; } \\
\text { iron oxide and manganese stains. }\end{array}$ & $\begin{array}{l}\mathrm{Cu}(24 \mathrm{ppm}), \mathrm{Pb}(12 \mathrm{ppm}) \\
\mathrm{Zn}(178 \mathrm{ppm}), \operatorname{Mo}(15 \mathrm{ppm}) \\
\operatorname{Mn}(319 \mathrm{ppm})\end{array}$ \\
\hline
\end{tabular}

Several samples of altered limestone were tested for low-grade gold resources. Gold was not detected in any of these samples, and other elements that may indicate gold mineralization were either not detected or were present in very low quantities (table 1 , samples 24 , $28,29)$. However, very low levels of gold (35 ppb (parts per billion)) were reported in sediment collected east of Crystal Peak in the northern part of the study area (Brown, 1987, sample 5) and within Area 2 of the southeastern part of the study area (Brown, 1987, sample 22).
Inferred subeconomic resources of limestone and dolomite suitable for industrial and agricultural uses are abundant throughout the study area. In the north an area of about $0.25 \mathrm{mi}^{2}$ contains high-silica sandstone and quartzite suitable for container glass and industrial uses. Chemical analyses of selected samples are reported in Brown (1987).

Limestone, dolomite, sandstone, and volcanic rocks suitable for roadfill or construction uses are present throughout the study area. However, abundant stone for these purposes is available closer to population 


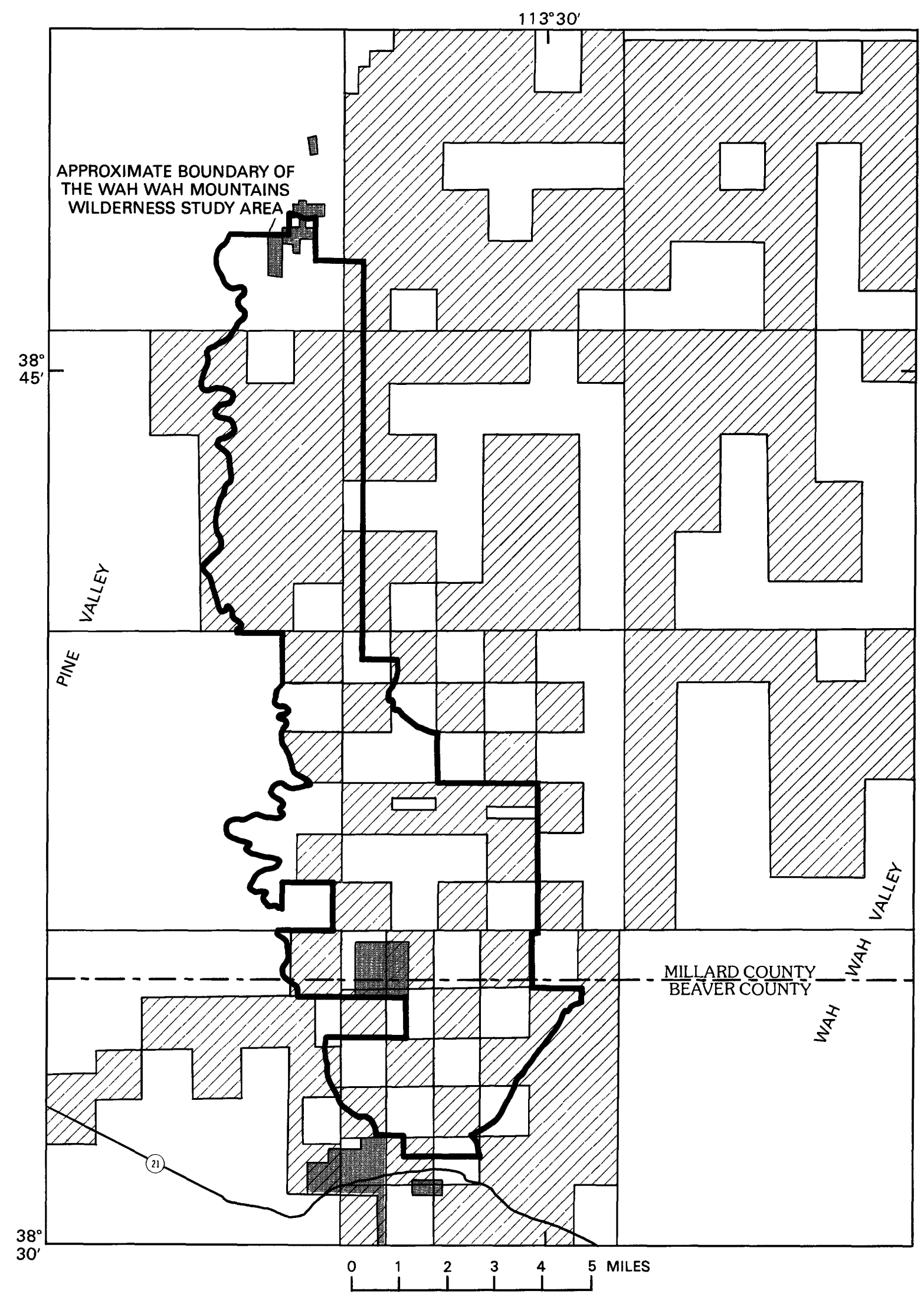

Figure 3 (above and facing page). Oil and gas leases and unpatented claims in the Wah Wah Mountains Wilderness Study Area, Utah. 


\section{EXPLANATION}

Oil and gas leases as of April 1986

General area of unpatented claims as of May 1985

centers and markets, making any development of those in the study area unlikely.

\section{ASSESSMENT OF POTENTIAL FOR UNDISCOVERED RESOURCES}

\section{By Leslie J. Cox, Karen A. Duttweiler, David L. Campbell, Joseph S. Duval, Melvin H. Podwysocki, Viki Bankey, and Kenneth L. Cook ${ }^{2}$ U.S. Geological Survey}

\section{Geology}

The bedrock underlying the Wah Wah Mountains Wilderness Study Area consists predominantly of stratified sedimentary rocks of early Paleozoic (Cambrian and Ordovician) age. Limestone and dolomite are most abundant; quartzite, sandstone, and shale are less abundant. Lying unconformably over the carbonate strata are limited areas of volcanic rocks that are remnants of once extensive Tertiary (Lemmon and others, 1973; Hintze, 1974b) volcanic tuffs and flows. Tertiary diorite and rhyolite stocks are exposed in the Wah Wah Summit area. A contact-metamorphic aureole extends as much as $1 \mathrm{mi}$ into the study area and may overlie unexposed stock(s) a short distance below the surface (Erickson, 1966; Hintze, 1974b). The aureole is characterized by local zones of marble, irregular zones of skarn, and argillaceous (feldspar altered to clay) igneous rock. The Wah Wah Mountains are cut and partly bounded by north-trending faults as a result of intense block faulting and extensional tectonism which began in early Miocene time. Elsewhere in western Utah, faults related to Basin and Range tectonism either localized eruption of early Miocene volcanic rocks or influenced their accumulation (Steven and Morris, 1984). Volcanic rocks of Miocene age are absent from the study area.

The sedimentary rocks in the study area are the remnants of the Wah Wah thrust sheet, which was displaced from the west to its present site during the Late

${ }^{2}$ University of Utah.
Cretaceous Sevier orogeny (Miller, 1966; Armstrong, 1968). During transport the sheet was warped into broad folds and cut by high-angle joints and faults. These joints and faults later served as channels for hydrothermal fluids associated with Oligocene and younger igneous activity. In the Wah Wah Mountains south of the study area, Paleozoic rocks of the allochthonous (transported) sheet overlie Jurassic and Triassic stratified rocks at depth (Miller, 1966). This relationship is supported by seismic geophysical data (Allmendinger and others, 1983,1985 ) in the study area as well. The Mesozoic rocks and thrust faults in the subsurface may have been suitable for oil and natural gas accumulation beneath the study area.

Throughout the western United States, erosion of areas uplifted by the Sevier orogeny resulted in deposition of Upper Cretaceous and lower Tertiary basin-fill sedimentary rocks in topographically low sites of the time. If present in the study area, these rocks would be in the subsurface of the valleys adjoining the Wah Wah Mountains. However, because few wells have been drilled, the stratigraphy of the valleys is not well known.

The volcanic rocks in the study area represent the earliest stages of a broad regional trend of volcanism that began in a relatively anorogenic (structurally quiet) period (early Oligocene) and continued episodically nearly to the present (Steven and Morris, 1984). During the early phases of this regional event, 35-30 m.y. (million years) ago, many scattered, intermediatecomposition stratovolcanoes formed, and a few regional ash-flow sheets accumulated (Rowley and others, 1979). At Crystal Peak (in the northern part of the study area), rhyolite ash-flow tuff as much as $1,280 \mathrm{ft}$ thick was derived from a small caldera a few (2-3) mi to the east (T.A. Steven, oral commun., 1988). The welded rhyolite tuff is dated at 33 m.y. (R.L. Armstrong, written commun., 1970, in Hintze, 1974b). In the southeastern corner of the study area, Lemmon and others (1973) mapped 32.5-33.6-m.y.-old rhyodacite to andesite lava flows that probably represent part of an old stratovolcano (Rowley and others, 1979). Representative rock units in the southeast include welded rhyolite tuff, porphyritic andesite agglomerate and flows, porphyritic rhyodacite; volcanic andesite flows; and volcanic porphyritic dacite flows and tuff that reach thicknesses greater than about $1,300 \mathrm{ft}$ (Hintze, 1974b). The relationship of the volcanic rocks in the northern part of the study area to those in the southeast is not established, but the sequences in the south are thought to come from sources tens of miles to the south and west (Rowley and others, 1979). Geochemical anomalies (tables 1 and 2) are associated with the volcanics in the southeastern (Areas 1-4, fig. 2) rather than in the northern part of the study area. 
Table 2. Selected data for rock, stream-sediment, and heavy-mineral panned-concentrate samples collected by the U.S. Geological Survey from the Wah Wah Mountains Wilderness Study Area and vicinity, Utah

[The sample number suffix indicates the sample type: $\mathrm{R}$, rock; S, stream sediment; and $\mathrm{C}$, panned concentrate. Sample localities shown on pl. 1 . Concentrations, in parentheses, in parts per million. $>$, more than. Semiquantitative spectrographic analyses by B.M. Adrian; inductively coupled plasma spectroscopy analyses by D.L. Fey and P.L. Hageman, all U.S. Geological Survey]

\begin{tabular}{|c|c|c|c|}
\hline $\begin{array}{l}\text { Sample } \\
\text { No. }\end{array}$ & $\begin{array}{l}\text { Area } \\
\text { No. }\end{array}$ & Sample description & $\begin{array}{c}\text { Elements and (anomalous } \\
\text { concentrations) }\end{array}$ \\
\hline JGWS017R & 1 & Iron- and manganese-stained skarn-- & $\mathrm{Zn}(420), \operatorname{As}(160), \mathrm{Cd}(5.9), \mathrm{Sb}(35)$ \\
\hline JGWSO 18R & 1 & Dark silicified limestone- & $\mathrm{Sb}(35), \mathrm{As}(160), \mathrm{Pb}(50)$ \\
\hline TUWWO01R & 1 & Altered vein breccia in limestone-- & $\operatorname{Zn}(2,000)$ \\
\hline KDWW009R & 1 & Altered limestone- & $\mathrm{Zn}(630), \operatorname{Mo}(30)$ \\
\hline TDWW003R & 1 & Reddish limestone-C & $\ln (510)$ \\
\hline CTMS006R & 1 & Altered rhyolite in skarn zone---- & $\mathrm{Zn}(340), \operatorname{Cd}(1.9), \operatorname{As}(45)$ \\
\hline TDESO04R & 2 & Iron-stained marble-- & $\mathrm{Zn}(340), \mathrm{Cd}(5)$ \\
\hline CTES006R & 2 & Iron-stained marble- & $\mathrm{Zn}(340), \mathrm{Cd}(1.9), \operatorname{As}(45)$ \\
\hline JGWW002R & 2 & Dark silicified limestone- & $\mathrm{Zn}(350), \operatorname{Cd}(4.5)$ \\
\hline JGES024R & 2 & Dark silicified limestone--- & $\mathrm{As}(90), \mathrm{Ba}(2,000), \mathrm{Mo}(50)$ \\
\hline CTESO03R & 2 & Iron-stained, silicified limestone- & As $(260), \operatorname{Mo}(50)$ \\
\hline KDES018R & 2 & Manganese-stained limestone-C- & $\mathrm{Ba}(5,000), \mathrm{Mo}(10)$ \\
\hline KDESO 16R & 2 & Limestone, limonitic alteration--- & $\mathrm{Mo}(15)$ \\
\hline KDES002R & 2 & Limonite-stained diorite-n & $\mathrm{Bi}(3)$ \\
\hline KDESO 13R & 2 & Limonite-stained, altered diorite-- & $\mathrm{Pb}(50), \mathrm{Bi}(6)$ \\
\hline TDMS001R & 2 & Skarn-C-- & $\mathrm{Pb}(70), \mathrm{Bi}(10)$ \\
\hline CTESO04R & 2 & Limestone-- & $\mathrm{Sb}(17)$ \\
\hline KDES006R & 2 & Skarn-r-mon & $B(300)$ \\
\hline JGWW001C & 2 & Heavy-mineral panned concentrate--- & $\mathrm{Ba}(5,000)$ \\
\hline CTWWOO IC & 2 & Heavy-mineral panned concentrate--- & $\mathrm{Ba}(2,000)$ \\
\hline JGWW003C & 3 & Heavy-mineral panned concentrate--- & $\mathrm{Sb}(3,000), \mathrm{Ba}(2,000)$ \\
\hline CTWW003C & 3 & Heavy-mineral panned concentrate-- & $\mathrm{Sb}(3,000)$ \\
\hline CTWW002C & 3 & Heavy-minera1 panned concentrate--- & $\mathrm{Sb}(500)$ \\
\hline JGWW00 8R & 4 & Altered volcanic rock & $\mathrm{Sb}(16), \mathrm{Ba}(1,000)$ \\
\hline CTWW005S & 4 & Stream sediment-- & $\mathrm{Sb}(9)$ \\
\hline JGWW005S & 4 & Stream sediment- & $\mathrm{Sb}(9)$ \\
\hline JGWW006S & 4 & Stream sediment- & $\mathrm{Cd}(0.8)$ \\
\hline CTWW004S & 4 & Stream sediment-- & $\mathrm{Cd}(1.0)$ \\
\hline JGWW002S & 4 & Stream sediment- & $W(1.2)$ \\
\hline JGWW004S & 4 & Stream sediment- & $W(1.7), \operatorname{Zn}(200), \operatorname{Cd}(1.4)$ \\
\hline CTWW005C & 4 & Heavy-mineral panned concentrate--- & $W(100)$ \\
\hline KDWW004C & 4 & Heavy-mineral panned concentrate--- & $\mathrm{Ba}(10,000)$ \\
\hline JGWW006C & 4 & Heavy-mineral panned concentrate--- & $\mathrm{Ba}(5,000)$ \\
\hline JGWW004C & 4 & Heavy-mineral panned concentrate--- & $\mathrm{Ba}(7,000)$ \\
\hline J GWW002C & 4 & Heavy-mineral panned concentrate--- & $\mathrm{Ba}(2,000)$ \\
\hline JGWW009R & Unnumbered & Limestone, veined-_ & $\mathrm{Ba}(3,000)$ \\
\hline JGWW0 1 1R & Unnumbered & Limes tone-- & $\mathrm{Sb}(16)$ \\
\hline JGWW009S & Unnumbered & Stream sediment- & $\mathrm{Sb}(12)$ \\
\hline CTWWO 10S & Un numbered & St ream sediment- & $\mathrm{Sb}(9)$ \\
\hline CTWW014R & Unnumbered & Silicified limestone(?)-- & $\operatorname{Mo}(10)$ \\
\hline & Unnumbered & $\begin{array}{l}\text { Chips of limestone breccia, red and } \\
\text { yellow ocher, and coarse calcite } \\
\text { from prospect pit. }\end{array}$ & $\mathrm{Sb}(150), \operatorname{As}(500), \operatorname{Mn}(>5,000), \mathrm{B}(2,000)$ \\
\hline
\end{tabular}


The diorite and rhyolite intrusions exposed in the Wah Wah Summit area are possibly coeval with some of the volcanic rocks in the southeastern corner of the study area (Erickson, 1966). Small dikes intrude the volcanic rocks east of Long Valley and possibly came from a hidden stock to the south or east. The igneous rocks lie within the westernmost boundary of an eastward-trending belt of abundant, shallow intrusions and calderas which become younger to the east (Steven and Morris, 1984) and which host base- (predominantly lead, zinc, and copper) and precious- (silver and gold) metal deposits (with associated antimony, bismuth, arsenic, and barium). The metal deposits in this belt are thought to have formed concurrently with the hydrothermal and intrusive activity (Steven and Morris, 1984).

Evidence of hydrothermal alteration associated with the Tertiary igneous activity was observed in the study area in Paleozoic carbonate rocks adjacent to exposures of igneous rock (Areas 1-4, fig. 2, pl. 1) and in areas where the volcanic rocks have since been eroded away (sample 98, pl. 1).

Widely exposed mineralized areas east of the Wah Wah Mountains and west of Milford were discovered mostly in the 1800's. Mining districts in the southern San Francisco Mountains and the Rocky Range (fig. 1) were exploited for metal deposits in skarn zones associated with the Oligocene and younger intrusions (Whelan, 1982; Steven and Morris, 1984).

\section{Geochemistry}

A reconnaissance geochemical survey was conducted in the Wah Wah Mountains Wilderness Study Area to aid in the assessment of mineral resource potential. A total of 49 stream-sediment and 49 heavymineral-concentrate samples were collected. A total of 181 rock samples were collected either from float in the stream channels, from outcrops, or from prospects and mines in or close to the study area. Analytical data and a description of the sampling and analytical techniques are given in Adrian, Gaccetta, and others (1988). The concentration ranges of selected elements in unaltered and altered rock samples are listed in table 3.

Few trace-element anomalies in stream-sediment samples from the study area can be attributed to mineralization. However, two general areas are defined by significant geochemical associations: (1) around Wah Wah Cove in the eastern part of the study area (Areas 3 and 4, pl. 1), and (2) near Wah Wah Summit along the southern boundary of the study area (Areas 1 and 2, pl. 1).

Stream-sediment samples from the Wah Wah Cove area are characterized by concentrations of iron, barium, nickel, lead, cobalt, chromium, vanadium, and manganese (Adrian, Gaccetta, and others, 1988), which reflect the composition of dacitic volcanic rocks exposed in the Wah Wah Cove area (Area 4, pl. 1). However, the sediment samples from Area 4 also contain high concentrations of elements that are unusual for unaltered carbonate or volcanic rocks in the study area. The concentrations of zinc (as much as $200 \mathrm{ppm}$ ), cadmium (as much as $1.4 \mathrm{ppm}$ ), and antimony (as much as 9 ppm) (table 2; Adrian, Gaccetta, and others, 1988) in the stream-sediment samples are greater than or equal to the highest values in the concentration ranges reported for unaltered carbonate and igneous rocks in the area (table 3). These high concentrations indicate that the stream sediments are in part derived from altered igneous and carbonate rocks (including skarn and marble) present in the area (see the ranges for altered igneous and carbonate rocks in table 3 ). Whereas most stream-sediment samples from the study area contained less than $1 \mathrm{ppm}$ tungsten, two samples from Area 4 contained 1.2 and $1.7 \mathrm{ppm}$ (table 2). Nonmagnetic heavymineral-concentrate samples from Area 4 contained high concentrations of barium (2,000-10,000 ppm) and tungsten (100 ppm) (table 2). Barite and pyrite were observed in several samples, and scheelite was observed in one. Nonmagnetic heavy-mineral-concentrate samples from Area 3 contained high concentrations of antimony (500-3,000 ppm) (table 2). No antimony-bearing minerals were identified. One rock from the Wah Wah Cove area (Area 4, pl. 1) altered by hydrothermal processes contained as much as $1,000 \mathrm{ppm}$ of barium and 16 ppm of antimony (table 2).

The Wah Wah Summit area (Areas 1 and 2, pl. 1) is characterized by rock samples with high concentrations of zinc, cadmium, arsenic, bismuth, antimony, and molybdenum. These rocks are generally at or near the contact between the carbonate rocks and the intrusions of diorite or rhyolite. The igneous rocks are weakly argillized, and the carbonate rocks locally are marble and contain skarn (Erickson, 1966). Small gossanlike bodies within the carbonate rocks contain hematite, limonite, and manganese oxides. Several of the geochemical anomalies are related to these iron- and manganese-rich zones. In Area 1, four samples of skarn and altered limestone (samples JGWS017R, JGWS018R, TDWW001R, and TDWW003R, pl. 1, table 2) contain 420-2,000 ppm zinc, and two samples contain high arsenic and antimony (table 2) where taken from small prospect pits with which iron and manganese oxides are associated. Farther east, in Area 2, iron and manganese oxide stained rocks contain high concentrations of zinc, cadmium, bismuth, arsenic, and molybdenum (table 2). In contrast, unaltered rocks, particularly those free of iron and manganese oxide coatings or stains, contain relatively low concentrations of metals (see ranges for unaltered carbonate and volcanic rocks in table 3 ). Although occurrences of sphalerite, galena, tetrahedrite, 
Table 3. Range of detectable concentrations of selected trace elements in rock samples from the Wah Wah Mountains Wilderness Study Area, Utah

[Analyses for $\mathrm{Au}, \mathrm{As}, \mathrm{Sb}, \mathrm{Zn}$, and $\mathrm{Cd}$ by inductively coupled plasma spectroscopy; all other elements by semiquantitative emission spectroscopy. Concentrations in parts per million, except $\mathrm{Fe}, \mathrm{Mg}, \mathrm{Ca}$, and $\mathrm{Ti}$, in weight percent; n, number of samples; >, greater than; n.d., not detected at lower limit of determination. Analyses by B.M. Adrian, D.L. Fey, and P.L. Hageman, U.S. Geological Survey]

\begin{tabular}{|c|c|c|c|c|c|c|}
\hline & $\begin{array}{l}\text { Unaltered } \\
\text { carbonate } \\
\text { rocks } \\
n=101\end{array}$ & $\begin{array}{c}\text { Unaltered } \\
\text { igneous rocks } \\
n=36\end{array}$ & $\begin{array}{c}\text { Marble } \\
\mathrm{n}=14\end{array}$ & $\begin{array}{l}{ }^{1} \text { Altered } \\
\text { carbonate } \\
\text { rocks } \\
n=72\end{array}$ & $\begin{array}{c}\text { Altered } \\
\text { igneous rocks } \\
n=19\end{array}$ & $\begin{array}{c}\text { Skarn } \\
n=21\end{array}$ \\
\hline $\begin{array}{l}\mathrm{Fe} \\
\mathrm{Mg} \\
\mathrm{Ca} \\
\mathrm{Ti}\end{array}$ & $\begin{array}{r}0.05-5 \\
0.07->10 \\
1->20 \\
0.002-0.5\end{array}$ & $\begin{array}{c}0.3-7 \\
0.05-10 \\
0.7-20 \\
0.003-1.0\end{array}$ & $\begin{array}{c}0.05-3 \\
0.7-7 \\
15-20 \\
0.002-0.3\end{array}$ & $\begin{array}{c}0.07-20 \\
0.07-20 \\
0.10-20 \\
0.002-0.15\end{array}$ & $\begin{array}{l}0.7-3 \\
0.2-2 \\
0.3-3 \\
0.01-0.7\end{array}$ & $\begin{array}{c}0.05-3 \\
1-10 \\
3-20 \\
0.007-0.5\end{array}$ \\
\hline $\begin{array}{l}\mathrm{Mn} \\
\mathrm{B} \\
\mathrm{Ba} \\
\mathrm{Be}\end{array}$ & $\begin{array}{l}210-5,000 \\
10-30 \\
20-3,000 \\
\text { n.d. }\end{array}$ & $\begin{array}{l}10-1,500 \\
10-30 \\
300-1,500 \\
21-3\end{array}$ & $\begin{array}{l}210-2,000 \\
210-30 \\
230 \\
\text { n.d. }\end{array}$ & $\begin{array}{l}10-5,000 \\
10-2,000 \\
30-5,000 \\
1-20\end{array}$ & $\begin{array}{l}30-1,000 \\
10-50 \\
200-1,000 \\
21-3\end{array}$ & $\begin{array}{l}100-2,000 \\
10-300 \\
20-1,000 \\
\text { n.d. }\end{array}$ \\
\hline $\begin{array}{l}\mathrm{Co} \\
\mathrm{Cr} \\
\mathrm{Cu} \\
\mathrm{Ni}\end{array}$ & 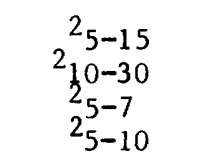 & $\begin{array}{l}5-50 \\
10-700 \\
5-30 \\
5-150\end{array}$ & 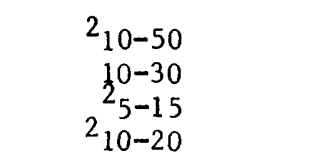 & $\begin{array}{l}25-50 \\
210-100 \\
25-20 \\
25-200\end{array}$ & $\begin{array}{c}5-50 \\
10-150 \\
5-50 \\
5-70\end{array}$ & $\begin{array}{r}5-15 \\
10-70 \\
210-30 \\
5-20\end{array}$ \\
\hline $\begin{array}{l}\mathrm{Pb} \\
\mathrm{Sr} \\
\mathrm{V} \\
\mathrm{Y} \\
\mathrm{Zr}\end{array}$ & $\begin{array}{l}{ }^{2} 10-20 \\
100-1,500 \\
210-150 \\
210-20 \\
210-150\end{array}$ & $\begin{array}{l}15-50 \\
200-2,000 \\
10-300 \\
10-30 \\
10-300\end{array}$ & $\begin{array}{l}210 \\
150-300 \\
10-30 \\
210-20 \\
10-50\end{array}$ & $\begin{array}{c}2{ }^{2} 10-100 \\
100-2,000 \\
210-300 \\
10-200 \\
10-200\end{array}$ & $\begin{array}{c}20-50 \\
200-700 \\
10-150 \\
15-20 \\
70-150\end{array}$ & $\begin{array}{l}10-70 \\
100-100 \\
15-150 \\
10-20 \\
30-200\end{array}$ \\
\hline & $n=43$ & $\begin{array}{l}\text { s analyzed by } \\
n=32\end{array}$ & $\begin{array}{l}\text { inductively coupled } \\
\qquad=13\end{array}$ & $\underset{n=55}{p l a s m a}$ spec & $\begin{array}{l}\text { roscopy } \\
n=18\end{array}$ & $\mathrm{n}=15$ \\
\hline $\begin{array}{l}\mathrm{Au} \\
\mathrm{As} \\
\mathrm{Sb} \\
\mathrm{Zn} \\
\mathrm{Cd}\end{array}$ & $\begin{array}{c}n \cdot d . \\
28-25 \\
2-8 \\
2-47 \\
0.1-0.6\end{array}$ & $\begin{array}{l}2_{20}^{\mathrm{n} \cdot \mathrm{d}} \cdot \\
2_{3} \\
10-50 \\
0.1-0.8\end{array}$ & $\begin{array}{c}n \cdot d \cdot \\
27-57 \\
2-16 \\
3-340 \\
0.1-1.9\end{array}$ & $\begin{array}{l}\text { n.d. } \\
25-260 \\
22-35 \\
2-2,000 \\
0.1-5.9\end{array}$ & $\begin{array}{l}\text { n.d. } \\
25-6 \\
25 \\
4-130 \\
0.1-0.7\end{array}$ & $\begin{array}{c}2_{15-160}^{n \cdot d} . \\
3-35 \\
5-630 \\
0.1-5.9\end{array}$ \\
\hline
\end{tabular}

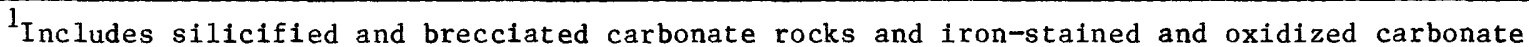
rocks.

${ }^{2}$ More than half of the samples contain concentrations below the limit of determination.

and tennantite would produce several of the geochemical anomalies described, no sulfide or sulfosalt minerals other than minor amounts of pyrite were observed in either the carbonate or volcanic rocks.

\section{Geophysics}

\section{Gravity Studies}

Gravity data for the study area (fig. 4) were compiled by K.L. Cook and Viki Bankey for a gravity map of Utah. There were nine gravity stations inside the wilderness study area and nine more on its borders, about one station per 2,500 acres. The gravity coverage, therefore, is insufficient to reflect small geological details in the wilderness study area.

The gravity data are, however, of sufficient detail to identify areas of structural displacement within the study area. Locations of intrusive bodies or faults are not identifiable by these data. Gravity values are high over the Wah Wah Mountains and low over the adjacent Pine Valley to the west (fig. 4). The relatively steep gravity gradient along the western side of the mountains reflects an inferred basin-range fault along which Pine Valley was downdropped relative to the mountains. A short gradient segment along the southeastern side of the study area may reflect a similar, unidentified basin-range fault. Overall, the gravity pattern near the southern part of the 
wilderness study area reflects the east-dipping, tilted fault block of the Wah Wah Mountains and the adjacent Wah Wah Valley to the east. To the north, gravity highs labeled " $\mathrm{H}_{\mathrm{a}}$ " (fig. 4) reflect the relatively dense rocks of the Wah Wah Mountains, whereas the southern extensions of the Confusion and House Ranges are reflected by gravity highs " $H_{b}$ " and " $H_{c}$ " (fig. 4), respectively. The gravity low labeled " $\mathrm{L}_{\mathrm{a}}$ " (fig. 4) at the northeastern edge of the study area may represent a sharply defined caldera, which is the interpretation suggested by T.A. Steven (oral commun., 1988).

\section{Seismic Studies}

In 1982 a deep-reflection seismic profile across western Utah was made through the east-tilted fault block of the House Range (fig. 1) at Marjum Pass, about $34 \mathrm{mi}$ north-northeast of the northern edge of the study area (Allmendinger and others, 1983, 1985). The profile showed reflectors at depths of about $1.8,2.5$, and $5 \mathrm{mi}$ that were interpreted to represent Mesozoic thrust faults; these reflectors bow upward in an antiform under the mountains. By analogy, a similar arch may exist beneath the similarly east-tilted fault block of the Wah Wah Mountains.

The tilted fault-block structure of the Wah Wah Mountains and the possible repetition of possibly petroliferous rock sequences associated with subhorizontal Mesozoic thrust faults would be favorable structural traps for oil (or natural gas) in the study area.

\section{Aeromagnetic Studies}

The aeromagnetic map of Utah (Zietz and others, 1976) shows a band of magnetic highs extending southsouthwest across the southern part of the Richfield $1^{\circ} \times 2^{\circ}$ quadrangle. These highs reflect the belt of Tertiary igneous rocks that crosses the Wah Wah Mountains in the Wah Wah Summit area (fig. 2, pl. 1). All but the southernmost part of the study area lies in a broad, magnetically featureless zone that occupies approximately the northern half of the Richfield $1^{\circ} \times 2^{\circ}$ quadrangle and the southern half of the adjacent Delta $1^{\circ} \times 2^{\circ}$ quadrangle to the north.

Aeromagnetic data were collected in 1972 along several north-south-trending lines crossing the study area (U.S. Geological Survey, 1972a, b). The data were gridded and contoured by J.L. Plesha and are shown in figure 5. Flight lines in that survey were spaced about $2 \mathrm{mi}$ apart and were flown at about 9,000-ft barometric elevation. Because the highest peaks in the Wah Wah Mountains reach elevations near $9,000 \mathrm{ft}$, it might be expected that the survey would give good definition of magnetic rocks that are both high in elevation and near flight lines but would miss altogether or give poor definition of magnetic bodies in the valleys and between flight lines. However, with these data, no substantial magnetic anomalies are evident in the wilderness study area. A second magnetic survey flown in 1979 at 2-mi spacing east-west and draped at $1,000 \mathrm{ft}$ above topography (U.S. Department of Energy, 1979) also shows the study area to be magnetically featureless. The rhyolite and diorite bodies exposed at Wah Wah Summit (fig. 2) are not distinguished by magnetic anomalies (fig. 5). Both magnetic surveys showed a magnetic high outside the wilderness study area near the southeastern boundary (site A, fig. 5). This magnetic high is centered over Wah Wah Springs, just south of State Highway 21 (fig. 1). The cause of this anomaly is a dioritic pluton that crops out along and north of Highway 21. The pluton probably is present under most of the magnetic high and extends at depth south and east of its outcrop area. The magnetic characteristics of the area indicate that the pluton extends to some depth; it probably is more than $10,000 \mathrm{ft}$ thick.

The magnetic surveys show the rocks within the study area to be uniformly low in intensity, and no large magnetically anomalous bodies are interpreted to be at depth.

\section{Radiometric Studies}

Radiometric data were collected in 1978 by an aerial survey conducted along several widely spaced (3 mi) east-west-trending lines crossing the study area (U.S. Department of Energy, 1979). The survey provided estimates of the near-surface (average depth of about 1 $\mathrm{ft}$ ) concentrations of percent potassium $(\mathrm{K})$, parts per million equivalent uranium ( $\mathrm{ppm} \mathrm{eU}$ ), and parts per million equivalent thorium (ppm eTh). The data for Utah were compiled and processed to produce a series of 1:1,000,000 scale maps, including the composite-color maps of Duval (1983). These maps were examined to estimate the $\mathrm{K}$, eU, and eTh concentrations for the wilderness study area and to identify anomalous radioelement concentrations. To be considered anomalous, the element concentration. as well as its ratios to the other two elements, must bc high in the context of values within the map area.

The overall radioactivity of the Wah Wah Mountains Wilderness Study Area estimated from the aerial survey is low, with concentrations of $0.6-2.0$ percent K, 0.5-2.0 ppm eU, and 2-6 ppm eTh. There are no indications of gamma-ray anomalies within or near the wilderness study area.

\section{Remote-Sensing Studies}

A Landsat Thematic Mapper (TM) data set (scene ID 50532-17381, Aug. 15, 1985) that covers all but the 

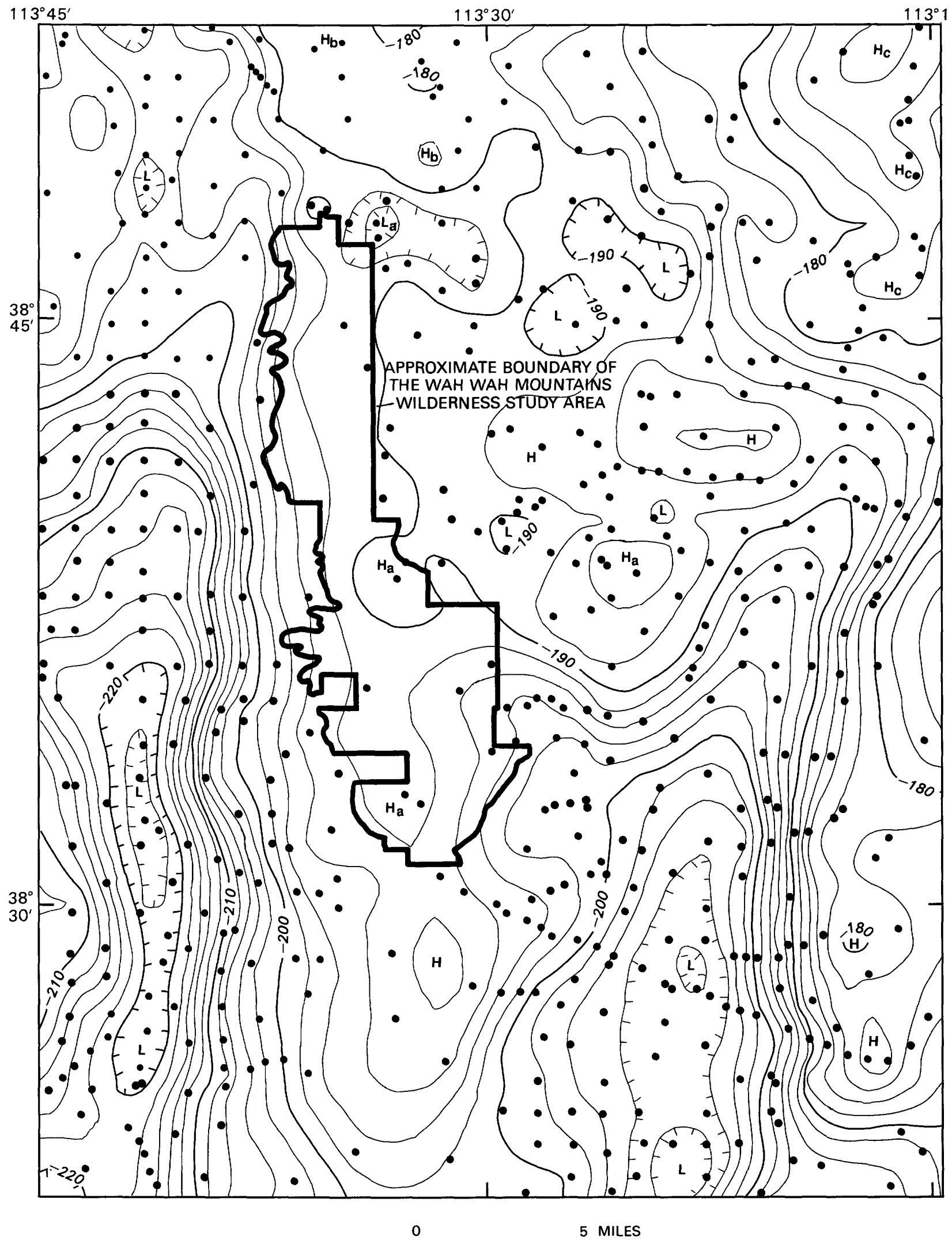
northwestern part of the study area was digitally processed and analyzed. Three TM band ratios (TM3/TM1, TM5/TM4, and TM5/TM7) were combined to create a color-ratio-composite (CRC) image that was used to identify sites that possibly contain hydrothermally altered, potentially ore-bearing rocks.

The CRC image was composed to emphasize the areas where rocks have a large percentage of minerals with high $\mathrm{Fe}^{+3}$ (ferric iron) content (for example, hematite, goethite, or jarosite-collectively referred to as limonitic minerals) or a high $\mathrm{OH}^{-1}$ (hydroxyl radical) content (for example, clay minerals, micas, or jarosite) or both. Spectral signatures indicative of rocks with either high content of hydroxyl-bearing minerals or both hydroxyl-bearing and limonitic minerals were considered anomalous; the corresponding areas possibly contain hydrothermally altered rocks. These areas are shown on plate 1.

However, the spectral signature for rocks with a high hydroxyl radical content is also characteristic of very bright carbonate $\left(\mathrm{CO}_{3}\right)$-rich rocks, especially bright limestones, dolomites, and their contact-metamorphosed equivalents. Therefore, the CRC image was interpreted in the context of the known geologic features in order to minimize the misinterpretation of bright carbonate beds as altered or ore-bearing rock.

Interpretation of the spectral signatures is shown in table 4. The areas are listed in table 4 from highest to lowest certainty of containing altered and possibly mineralized rocks. The areas located on the CRC image correspond well with areas recognized on the ground as containing hydrothermally altered rocks (Areas 1-5, fig. 2, pl. 1).

\section{Mineral and Energy Resources}

In the Wah Wah Summit area of the Wah Wah Wilderness Study Area, iron oxide prospects and small gossans hosted by carbonate strata are characterized by high concentrations of zinc, cadmium, antimony, molybdenum, lead, arsenic, bismuth, and manganese. These metal occurrences are in a zone where igneous rocks intrude stratified carbonate rocks and are attributed to episodes of epithermal mineralization related to the Tertiary igneous rocks.

By analogy to mineral deposits of similar geologic setting east of the study area, undiscovered zinc, cadmium, antimony, tungsten, molybdenum, lead,

Figure 4 (facing page). Complete Bouguer gravity anomaly map of the Wah Wah Mountains Wilderness Study Area and vicinity, Utah. Reduction density, 2.67 grams per cubic centimeter. Contour interval, 2 milligals. Hachures indicate closed areas of lower gravity values. L, gravity low; $\mathrm{H}$, gravity high; subscripts explained in text; dots are station locations. arsenic, or bismuth deposits in the study area are most likely to occur within structurally favorable zones of carbonate rocks as vein and replacement bodies formed during Tertiary igneous activity. Also, by analogy, polymetallic deposits of lead, antimony, and bismuth may occur in igneous breccia near the top of hidden intrusions; skarn deposits of zinc-lead sulfides and possibly scheelite may be found close to the intrusive contacts.

\section{Epithermal Vein and Replacement Bodies}

In the southern San Francisco Mountains (fig. 1), east of the study area, vein and replacement bodies were uncommonly rich and large and were mined for zinc, lead, silver, gold, and minor copper (Steven and Morris, 1984). Generally, this type of deposit is small (3-35 ft wide and 500-670 ft long) and consists of podlike to tabular replacement bodies and fissure-filling veins of oxidized material localized along fractures cutting limestone and dolomite, bedding-plane faults, or other pre-existing solution channels (Steven and Morris, 1984). Replacement occurred by solutions emanating from nearby volcanic centers and plutons (Morris, 1986). Carbonate host rocks are generally dolomitized and silicified; shale and igneous hosts may be argillized (Morris, 1986). The geochemical signature of polymetallic replacement deposits typically includes anomalous amounts of copper, zinc, silver, bismuth, lead, antimony, arsenic, and manganese (in a few places there may be small amounts of gold) in rock samples; the mineralogy of the gangue (the valueless minerals that accompany ores) typically consists of quartz, pyrite, marcasite, and barite (Morris, 1986).

One type of antimony deposit is characterized largely by stibnite and associated pyrite, arsenopyrite, cinnabar, or scheelite or of antimony sulfosalts with varying amounts of the common sulfides of copper, lead, silver, and zinc (Miller, 1973). These deposits occur in settings similar to that of the polymetallic deposits: in fissures and shear zones with breccia (fault associated) and as replacement of surrounding rocks. The deposits are associated with polymetallic veins as well as tungsten skarn, disseminated mercury, and several varieties of gold deposits (Bliss and Orris, 1986).

The geology and geochemistry of rocks of the Wah Wah Summit area (Areas 1 and 2, pl. 1) are similar to the model for polymetallic replacement deposits described above. Areas 1 and 2 are distinguished by high concentrations of zinc, cadmium, antimony, molybdenum, arsenic, and bismuth in rock samples taken near the contact between intrusive igneous rocks and carbonate rocks. Carbonate rocks adjacent to the igneous intrusions are altered to marble or skarn; farther from the contact carbonate rocks are locally silicified. Small 

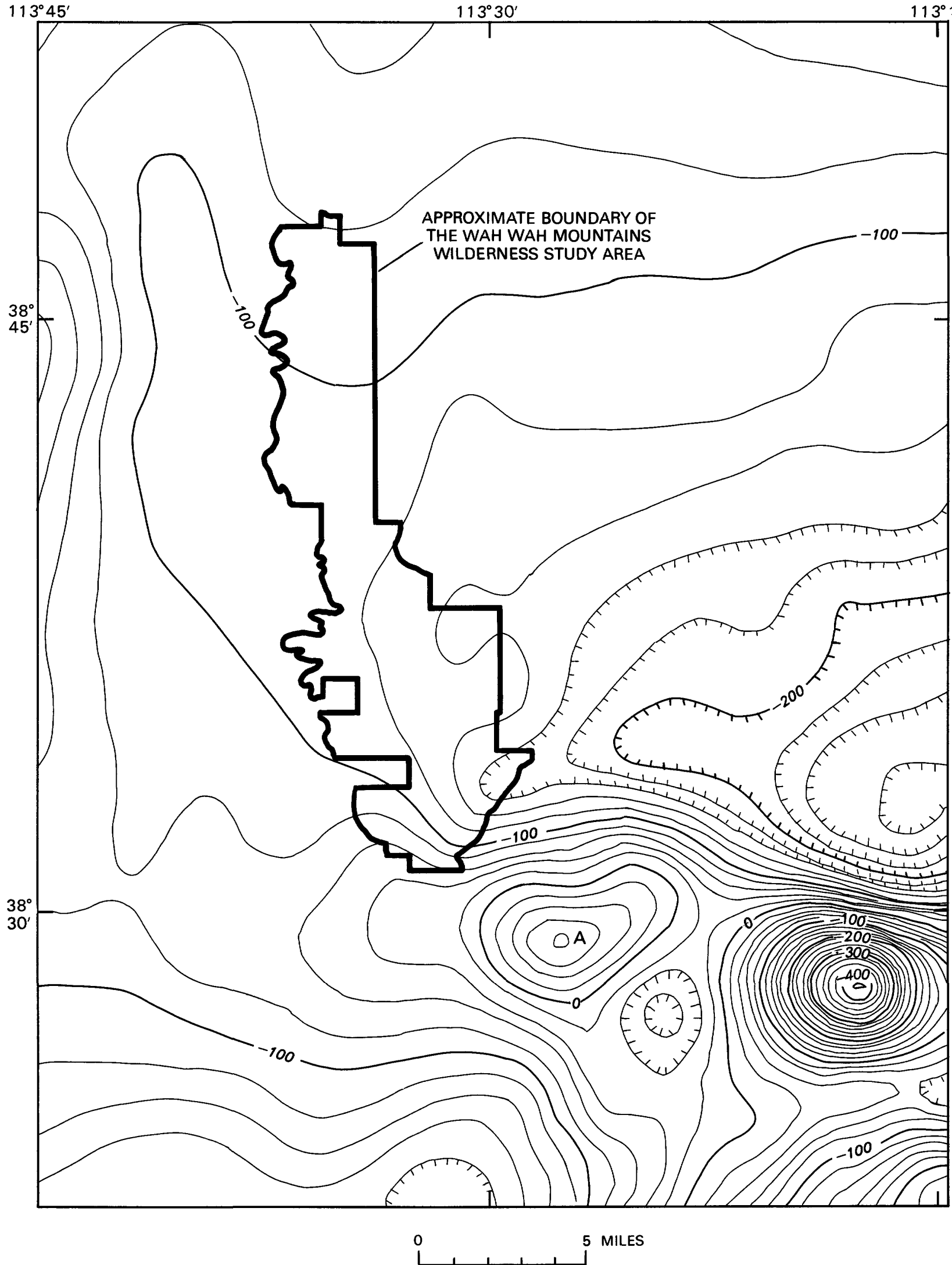

Figure 5. Aeromagnetic map of the Wah Wah Mountains Wilderness Study Area and vicinity, Utah. Contour interval, 20 nanoteslas. Hachures indicate closed areas of lower magnetic intensity. A, magnetic high discussed in text. 
Table 4. Summary of areas having spectral signatures characteristic of hydrothermally altered rock, determined from Landsat Thematic Mapper data, Wah Wah Mountains Wilderness Study Area, Utah

\begin{tabular}{|c|c|c|}
\hline Location (pl. 1) & Interpretation of spectral signature & Geologic correlation \\
\hline $\begin{array}{l}\text { Area } 1: \\
\text { secs. } 27,28,29 \\
\text { T. } 26 \text { S., R. } 15 \text { W. }\end{array}$ & $\begin{array}{l}\text { Bleached rocks with weak oH or } \\
\text { strong carbonate }\left(\mathrm{CO}_{3}\right)\end{array}$ & $\begin{array}{l}\text { Bright contact-metamorphosed carbonate } \\
\text { rocks (marbles). }\end{array}$ \\
\hline $\begin{array}{l}\text { Area } 2: \\
\text { S } 1 / 2 \text { sec. } 15, \\
\text { T. } 26 \text { S., R. } 15 \text { W. }\end{array}$ & $\begin{array}{l}\text { Limonitic rocks with weak } \mathrm{OH} \text { or } \\
\text { strong } \mathrm{CO}_{3} \cdot\end{array}$ & $\begin{array}{l}\text { Silicified ferruginous volcanic breccias, } \\
\text { weakly altered, and contact- } \\
\text { metamorphosed carbonate rocks (marbles). }\end{array}$ \\
\hline $\begin{array}{l}\text { Area } 4: \\
\mathrm{N} 1 / 2 \text { secs. } 1,2, \\
\text { T. } 26 \text { S., R. } 15 \mathrm{~W}\end{array}$ & $\begin{array}{l}\text { Limonitic rocks with weak } \mathrm{OH} \text { or } \\
\text { strong } \mathrm{CO}_{3} \cdot\end{array}$ & Extrusive volcanic rocks, weakly altered. \\
\hline $\begin{array}{l}\text { Area } 4: \\
\mathrm{N} 1 / 2 \mathrm{NE} 1 / 4 \mathrm{SE} 1 / 4 \\
\text { sec. } 31, \mathrm{~T} \cdot 25 \mathrm{~S} . \\
\text { R. } 15 \mathrm{~W} \text {. }\end{array}$ & $\begin{array}{l}\text { Slightly limonitic rocks with weak } \\
\text { OH or strong } \mathrm{CO}_{3} \text {. }\end{array}$ & $\begin{array}{l}\text { Paleozoic carbonate rocks; anomalous area } \\
\text { is on fault. }\end{array}$ \\
\hline $\begin{array}{l}\text { NW } 1 / 4 \text { NW } 1 / 4 \text { sec. } 23 \text {, } \\
\text { T. } 25 \text { S., R. } 15 \text { W. } \\
\text { SW } 1 / 4 \text { SW } 1 / 4 \text { sec. } 13 \text {; } \\
\text { N } 1 / 2 \text { SW } 1 / 4 \text { NW } 1 / 4 \\
\text { sec. } 24, \text { T. } 25 \mathrm{s.}, \\
\text { R. } 16 \text { W. }\end{array}$ & $\begin{array}{l}\text { Bleached rocks with strong } \mathrm{OH} \text { or very } \\
\text { strong } \mathrm{CO}_{3} \text {. Similar to Area } 1 \text {. } \\
\text { Limonitic rocks with weak } \mathrm{OH} \text { or } \\
\text { strong } \mathrm{CO}_{3} \text {. }\end{array}$ & $\begin{array}{l}\text { Paleozoic rocks--spectral signature } \\
\text { similar to Area 1; not field checked. } \\
\text { Bright Paleozoic carbonate rocks; not all } \\
\text { localities field checked. }\end{array}$ \\
\hline $\begin{array}{l}\text { S } 1 / 2 \text { sec. } 36, \\
\text { T. } 25 \text { S., R. } 16 \mathrm{~W} .\end{array}$ & $\begin{array}{l}\text { Slightly limonitic with weak } \mathrm{OH} \text { or } \\
\text { strong } \mathrm{CO}_{3} \text {. }\end{array}$ & $\begin{array}{l}\text { Paleozoic carbonate rocks; anomalous area } \\
\text { is on fault; not field checked. }\end{array}$ \\
\hline $\begin{array}{l}\text { SW } 1 / 4 \mathrm{NW} 1 / 4 \mathrm{SW}^{1 / 4} \\
\text { sec. } 25, \mathrm{~T} \cdot 26 \mathrm{~S} . \\
\text { R. } 15 \text { W. }\end{array}$ & $\begin{array}{l}\text { Slightly limonitic with weak } \mathrm{OH} \text { or } \\
\text { or strong } \mathrm{CO}_{3} \text {. }\end{array}$ & $\begin{array}{l}\text { Tertiary volcanic extrusive rocks; not } \\
\text { field checked. }\end{array}$ \\
\hline $\begin{array}{l}\mathrm{N} 1 / 2 \mathrm{NW} l / 4 \text { sec. } 19 \\
\text { T. } 24 \text { S., R. } 15 \mathrm{~W} \text {. }\end{array}$ & $\begin{array}{l}\text { Slightly limonitic with weak } \mathrm{OH} \text { or } \\
\text { strong } \mathrm{CO}_{3} \text {. }\end{array}$ & Relatively bright limestone. \\
\hline $\begin{array}{l}\text { SE } 1 / 4 \mathrm{NW} 1 / 4 \mathrm{NE} 1 / 4 \\
\text { sec. } 17, \mathrm{~T} .25 \mathrm{~S} . \\
\text { R. } 15 \mathrm{~W} ; \mathrm{SE} 1 / 4 \\
\text { NW } 1 / 4 \mathrm{NW} 1 / 4 \text { Sec. } 8 \text {, } \\
\text { T. } 25 \mathrm{~S} ., \mathrm{R} .15 \mathrm{~W} \text {. }\end{array}$ & Bleached strong $\mathrm{OH}$ or strong $\mathrm{CO}_{3}$. & $\begin{array}{l}\text { Relatively bright Paleozoic carbonate } \\
\text { rocks. }\end{array}$ \\
\hline
\end{tabular}

gossanlike bodies and veins within the carbonate rocks contain hematite, limonite, and manganese oxides. Area 2 also shows the characteristics of the antimony deposit type described above. Brecciated chert lenses in limestone near the contact with andesite contain low levels of mercury (table 1$)$. Gold ( $20 \mathrm{ppb}$ ) was detected in a stream-sediment sample taken downstream from the mercury-bearing rock (Brown, 1987, sample 22).

Although the majority of the metal anomalies in the Wah Wah Summit area may be derived from the roots of Tertiary mineral deposits that have for the most part been eroded away, Areas 1 and 2 may yet contain one or more types of small epithermal vein and replacement bodies.
Mineral resource potential.-Areas 1 and 2 (pl. 1, fig. 2) have moderate mineral resource potential, at certainty level $\mathrm{B}$, for zinc, cadmium, antimony, molybdenum, lead, arsenic, and bismuth in carbonatehosted vein and replacement bodies formed during episodes of epithermal mineralization originating with Tertiary igneous activity. In addition, Area 2 has moderate potential, with certainty level $\mathrm{B}$, for the occurrence of gold in carbonate-hosted vein and replacement deposits.

High concentrations of antimony and barium were reported from the stream-sediment and pannedconcentrate samples (table 2) collected from the basins in the Wah Wah Cove area (Areas 3 and 4, pl. 1). 
Drainage basins in which volcanic rocks crop out (Area 4, pl. 1) also contained detectable levels of tungsten in the stream-sediment samples as well as anomalously high concentrations of antimony, tungsten, and barium in nonmagnetic heavy-mineral panned concentrates. Altered rocks observed upstream from the tungstenbearing samples include hematite-bearing and silicified cherty limestone.

Several faults older than the Tertiary volcanic rocks cut the carbonate strata in Areas 3 and 4. A mile-long, north-trending fault cuts through the drainage basin from which the nonmagnetic heavy-mineral fraction sample JGWW003C contained 3,000 ppm of antimony (Area 3, pl. 1). A slightly longer north-trending fault cuts through two drainage basins from which the nonmagnetic heavy-mineral-fraction samples CTWW003C and CTWW002C contained 3,000 and 500 ppm of antimony, respectively (Area 3, pl. 1). These faults may have served as channels for ore-bearing solutions emanating from the intrusive igneous activity in areas to the south and west, areas interpreted to be favorable for polymetallic replacement deposits. Antimony deposits may form in faults and shear zones that are peripheral to polymetallic vein, skarn, and disseminated mercury deposits lying closer to subvolcanic igneous intrusions (Bliss and Orris, 1986). Antimony sulfides may be present along the faults in Area 3.

Areas 3 and 4 (pl. 1, fig. 2) have moderate mineral resource potential, at certainty level $\mathrm{B}$, for deposits containing antimony within carbonate- or volcanic-rockhosted vein and replacement bodies formed during episodes of epithermal mineralization originating with Tertiary igneous activity. Area 4 has concentrate samples with anomalous concentrations of tungsten. Therefore, Area 4 also has moderate mineral resource potential at certainty level B for tungsten.

North of the Wah Wah Summit and Wah Wah Cove areas are dispersed occurrences of metal-bearing rocks (unnumbered areas, table 2). A small prospect pit (loc. 98, pl. 1), examined during the field study, contains iron oxides interstitial to limestone breccia surrounded by reddened, dolomitized wall rock. Coarsely crystalline calcite fills vugs and veins within the brecciated rock. Anomalously high levels of antimony, arsenic, manganese, and boron were reported in the brecciated rock (sample 98, table 2). Although no igneous rocks crop out in the vicinity, the evident hydrothermal nature of the alteration suggests that ore solutions passed through the brecciated zone of carbonate rock that served as a channel for deposition of the metals. Remote-sensing data indicate the presence of small areas containing limonite-bearing rocks (table 4), and $10 \mathrm{ppm}$ of molybdenum were detected in a nearby sample (table 2).
The evidence for metal accumulation north of the Wah Wah Summit and Wah Wah Cove areas is scattered, and the geochemical anomalies are weak (samples from unnumbered areas, table 2). Therefore, these areas have low mineral resource potential, at a certainty level C, for accumulations of zinc, cadmium, antimony, tungsten, molybdenum, lead, arsenic, bismuth, or gold in carbonate-hosted vein and replacement deposits.

\section{Igneous Breccia-Hosted Deposits}

Pyrite, chalcopyrite, tetrahedrite, and galena ores were mined from the southern San Francisco Mountains mining district (fig. 1) east of the study area. The ore, as well as the gangue minerals tourmaline, quartz, iron carbonate and oxide minerals, anhydrite, and barite, filled open spaces in tabular to pipelike masses of igneous breccia, generated by the forceful intrusion of stocks, found at the exposed cupolas (tops) of the igneous intrusions and in associated lower volcanics (Steven and Morris, 1984, p. 25). These minerals are the source of anomalously high levels of iron, copper, and boron, as well as antimony, lead, and barium in geochemical samples from the San Francisco mining district.

The possibility of ore minerals interstitial to igneous breccia in the study area is limited to the southeasternmost area (Area 2, pl. 1) where subsurface extensions of the exposed and aeromagnetically identified stocks may be present. Andesitic volcanic flows and agglomerate that overlie Paleozoic carbonate strata may conceal the northern extension of the easternmost stock exposed in the Wah Wah Summit area. Diorite dikes that intrude the volcanic rock may have emanated from that stock. Small bodies of skarn adjoin the northern edge of the volcanic rock; at the surface the skarn bodies appear unrelated to intrusive rocks, but they may be related below the surface.

Relatively high concentrations of lead (200-2,000 ppm) were reported in a nonmagnetic heavy-mineralconcentrate sample (Miller and others, 1985b) collected in Area 2 (fig. 2), as well as 10-20 ppm bismuth (Miller and others, 1985a), which are comparable to the levels in samples collected from mining districts in the western Richfield quadrangle, for example, in the Beaver Lake, Staats, and Pine Grove mining districts (Miller and others, 1985a, b). Rock samples collected near the contact between altered igneous breccia and skarn exposed along the boundary of the easternmost stock in the Wah Wah Summit area (Area 2, pl. 1) contain moderate levels of lead, antimony, and bismuth (table 2, samples KDES002R, KDES013R, and CTES004R). Silicified limestone (hypothetically overlying the northern extension of an igneous intrusion) contains low levels of arsenic, barium, and molybdenum (table 2, sample JGES024R), about $1 \frac{1 / 2}{2}$ mi northeast of the area of igneous breccia mapped by Erickson (1966). 
Although the geochemical and geological evidence is compatible with the interpretation that small polymetallic vein and replacement bodies (as discussed in the section above) may be present in Area 2, the model described in this section is an alternative to the first interpretation. The geochemical data may represent antimony, lead, and other sulfides and barite gangue concealed in cupola breccia.

Mineral resource potential.-Area 2 (fig. 2, pl. 1) has moderate mineral resource potential, at certainty level B, for lead and antimony, and for associated bismuth, arsenic, molybdenum, zinc, cadmium, and gold in deposits hosted by concealed igneous breccia. Outside of Area 2, the study area has low mineral resource potential, at certainty level $\mathrm{C}$, for lead and antimony in deposits hosted by concealed igneous breccia.

\section{Skarn-Hosted Deposits}

Wall rock, particularly carbonate rock, adjacent to igneous intrusions is susceptible to hydrothermal alteration to skarn and to the accumulation of introduced metals. In the Rocky mining district in the Rocky Range east of the study area (fig. 1), copper deposits have been mined, and magnetite, tungsten, gold, and silver have been recovered as byproducts in skarn zones associated with the Oligocene and younger intrusions (Whelan, 1982; Steven and Morris, 1984). In the mining districts in the Rocky Range and San Francisco Mountains, scheelite deposits have been described as erratic and discontinuous, but they occur close to the igneous contact where garnet is abundant (in the San Francisco district) and where magnetite is abundant (in the Rocky mining district) in limestone beds especially suitable for replacement (Hobbs, 1945). Scheelite occurs so close to the contact that Hobbs (1945) described some deposits as forming "a mere skin" on the igneous body.

The contact-metamorphic aureole associated with the stocks in the Wah Wah Summit area extends as much as $1 \mathrm{mi}$ into the study area and may overlie an unexposed stock a short distance below the surface (Erickson, 1966). Manganese oxide stained gossan and alteration products indicative of covered zinc-lead skarn deposits (Cox, 1986) occur in Area 1 (pl. 1) where altered carbonate rocks contain high concentrations of zinc and lead (table 2) and detectable concentrations of tungsten (table 1). Tungsten (70 ppm) was reported in a heavymineral-concentrate sample (Miller and others, 1985c) from a basin draining Area 2 (pl. 1).

In the San Francisco mining district (fig. 1), scheelite occurs in the impure (rather than the pure) meta-limestones in close contact with the igneous intrusions in deposits extending to $300-\mathrm{ft}$ depths (Hobbs,
1945). In the study area, the likely areas of scheelite occurrence are where the igneous intrusions in the Wah Wah Summit area are in contact with shaly and dolomitic limestones.

Mineral resource potential.-Areas 1 and 2 (fig. 2, pl. 1) have moderate mineral resource potential, at certainty level B, for zinc, lead, and tungsten in skarnhosted deposits associated with subsurface extensions of the exposed intrusions in the Wah Wah Summit area. The absence of evidence of intrusive rock elsewhere in the study area indicates that outside of Areas 1 and 2 the study area has low mineral resource potential, at certainty level C, for zinc, lead, and tungsten in skarnhosted deposits.

\section{Oil and Gas}

The factors critical to generation, migration, and trapping of oil and gas include the presence of source rocks, reservoir rocks, structural or stratigraphic traps, and caprocks or seals. The analysis of oil and gas potential in the eastern part of the Basin and Range province relies heavily upon the interpreted presence and distribution in the subsurface of such rocks and traps. An evaluation of thermal maturation of source rocks (key to generation and expulsion of oil and gas) and the timing of oil and gas generation and migration relative to trap formation must also be considered.

Drilling west of the Confusion Range (fig. 1) north of the study area has indicated that source rocks are present in the sequence consisting of Cambrian and Ordovician rocks (Mitchell, 1979). The study area lies within an area in western Utah in which the Mississippian rocks, where present, constitute rich source rocks (Molenaar and Sandberg, 1983). However, Mississippian rocks are not exposed at the surface of the study area. The study area lies within an area that has a favorable thermal history for oil and gas generation (Molenaar and Sandberg, 1983). Favorable structural traps in the subsurface of the study area are indicated by the seismic geophysical evidence.

Large oil and gas fields have been discovered in the thrust-belt province of northern Utah and western Wyoming. There, subthrust Mesozoic rocks (mainly Cretaceous) are source rocks for overlying (Paleozoic, Triassic, and Jurassic rocks) reservoirs and traps (Powers, 1983). Mitchell (1979) suggested that the potential for existing oil and gas fields in the MesozoicPaleozoic sequence in parts of the eastern part of the Basin and Range province should be the same as the potential for equivalent units in the northern Utahwestern Wyoming part of the productive thrust belt to the north.

In several places in the eastern Basin and Range province, Paleozoic rocks have been hypothesized 
(Mitchell, 1979) and observed to lie unconformably above Mesozoic and older sequences of rocks. This relationship was observed by Miller (1966) in the southern part of the Wah Wah Mountains. The geophysical data for the region support the conclusion that in the study area (the northern Wah Wah Mountains) the Paleozoic rocks at the surface also lie unconformably over Mesozoic rocks in the subsurface. Where Tertiary rocks cover allochthonous Paleozoic and Mesozoic rocks, only very deep wells would penetrate all the way to the subthrust (Mesozoic and older sequence) rocks of interest.

Basin and Range province tectonism may have destroyed previously trapped oil and gas accumulations by the mechanics of extensional faulting and by groundwater flushing through fractures. However, the faults and fractures that might have leaked oil and gas to the surface are presumed to have been at least partly sealed prior to the cycle of hydrocarbon generation thought to be presently in progress (Molenaar and Sandberg, 1983).

The wilderness study area has moderate energy resource potential, at certainty level B, for oil and gas accumulation in the subsurface sedimentary rocks.

\section{Uranium}

Low gamma-ray levels and the absence of either uranium occurrences or geochemical anomalies indicate that the wilderness study area has low potential, at certainty level $\mathrm{C}$, for uranium resources.

\section{Geothermal Energy}

The Basin and Range province in general is characterized by high heat flow, thin crust, thermal springs, pervasive extensional faulting and seismicity, areas with thermally insulating basin-fill deposits, and young silicic volcanism (Grose and Keller, 1979), all of which may allow the localization of geothermal energy resources. However, the absence of thermal springs and the lack of large areas of thick, thermally insulating basin-fill deposits in the study area indicate that it has low potential, at certainty level $\mathrm{C}$, for geothermal energy resources.

\section{REFERENCES CITED}

Adrian, B.M., Gaccetta, J.D., Hopkins, R.T., Fey, D.L., and Duttweiler, K.A., 1988, Analytical results and sample locality maps of stream-sediment, heavy-mineralconcentrate, magnetic concentrate, and rock samples in and adjacent to the Wah Wah Mountains Wilderness Study Area, Utah: U.S. Geological Survey Open-File Report 88-535, $37 \mathrm{p}$.

Adrian, B.M., Hageman, P.L., Cox, L.J., and Panter, K.S., 1988, Analytical results and sample locality map of soil and rock samples from the Wah Wah Mountains Wilderness
Study Area (UT-050-073/040-205), Beaver and Millard Counties, Utah: U.S. Geological Survey Open-File Report 88-232, 26 p.

Allmendinger, R.W., Sharp, J.W., Von Tish, Douglas, Oliver, J.E., and Kaufman, Sidney, 1985, A COCORP crustalscale seismic profile of the Cordilleran hingeline, eastern Basin and Range province, Utah, in Gries, R.R. and others, eds., Seismic exploration of the Rocky Mountain region: Denver, Colo., Rocky Mountain Association of Geologists and Denver Geophysical Society, p. 23-30.

Allmendinger, R.W., Sharp, J.W., Von Tish, Douglas, Serpa, Laura, Brown, Larry, Kaufman, Sidney, Oliver, J.E., and Smith, R.B., 1983, Cenozoic and Mesozoic structure of the eastern Basin and Range province, Utah, from COCORP seismic-reflection data: Geology, v. 11, p. 532-536.

Armstrong, R.L., 1968, Sevier thrust belt in Nevada and Utah: Geological Society of America Bulletin, v. 79, p. 429-458.

Bliss, J.D., and Orris, G.J., 1986, Descriptive model of simple Sb deposits, in Cox, D.P., and Singer, D.A., eds., Mineral deposit models: U.S. Geological Survey Bulletin 1693, p. 183.

Brown, S.D., 1987, Mineral resources of a part of the Wah Wah Mountains Wilderness Study Area (UT-050-073/ 040-205), Beaver and Millard Counties, Utah: U.S. Bureau of Mines Open File Report MLA 1-87, 16 p.

Bullock, K.C., 1970, Iron deposits of Utah: Utah Geological and Mineralogical Survey Bulletin 88, $161 \mathrm{p}$.

Cox, D.P., 1986, Descriptive model of $\mathrm{Zn}$-Pb skarn deposits, in Cox, D.P., and Singer, D.A., eds., Mineral deposit models: U.S. Geological Survey Bulletin 1693, p. 90.

Dunn, D.E., 1959, Geology of the Crystal Peak area, Millard County, Utah: Dallas, Southern Methodist University M.S. thesis, $54 \mathrm{p}$.

Duval, J.S., 1983, Composite color images of aerial gamma-ray spectrometric data: Geophysics, v. 48, p. 722-735.

Erickson, M.P., 1966, Igneous complex at Wah Wah Pass, Beaver County, Utah: Utah Geological and Mineralogical Survey Special Studies, no. 17, 14 p.

Goudarzi, G.H., compiler, 1984, Guide to preparation of mineral survey reports on public lands: U.S. Geological Survey Open-File Report 84-787, $42 \mathrm{p}$.

Grose, L.T., and Keller, G.V., 1979, Geothermal energy in the Basin and Range Province, in Newman, G. W., and Goode, H. D., eds., Basin and Range Symposium: Rocky Mountain Association of Geologists and Utah Geological Association, p. 361-369.

Hintze, L.F., 1974a, Preliminary geologic map of the Crystal Peak quadrangle, Millard County, Utah: U.S. Geological Survey Miscellaneous Field Studies Map MF-635, scale $1: 48,000,2$ sheets.

1974b, Preliminary geologic map of the Wah Wah Summit quadrangle, Millard and Beaver Counties, Utah: U.S. Geological Survey Miscellaneous Field Studies Map MF-637, scale 1:48,000, 2 sheets. 
Hintze, L.F., Lemmon, D.M., and Morris, H.T., 1984, Geologic map of the Frisco Peak quadrangle, Millard and Beaver Counties, Utah: U.S. Geological Survey Miscellaneous Investigations Series Map I-1573, scale 1:62,500.

Hobbs, S.W., 1945, Tungsten deposits in Beaver County, Utah: U.S. Geological Survey Bulletin 945-D, p. 81-111.

Huntsman, J.R., 1981, Geology and mineral resources of the Richfield $1^{\circ} \times 2^{\circ}$ NTMS quadrangle, Utah, [in] Geology of the Delta, Escalante, Price, Richfield, and Salina $1^{\circ} \times 2^{\circ}$ NTMS quadrangles, Utah, National Uranium Resources Evaluation Program: U.S. Department of Energy report GJBX-31'82, p. 87-108. Available from Books and Open-File Reports Section, U.S. Geological Survey, Federal Center, Box 25425, Denver, CO 80225.

Lemmon, D.M., Silberman, M.L., and Kistler, R.W., 1973, Some K-Ar ages of extrusive and intrusive rocks of the San Francisco and Wah Wah Mountains [Utah], in Hintze, L.F., and Whelan, J.A., eds., Geology of the Milford area: Utah Geological Association Publication 3, p. 23-26.

Miller, G.M., 1966, Structure and stratigraphy of southern part of Wah Wah Mountains, southwest Utah: American Association of Petroleum Geologists Bulletin, v. 50, p. 858-900.

Miller, M.H., 1973, Antimony, in Brobst, D.A., and Pratt, W.P., eds., United States mineral resources: U.S. Geological Survey Professional Paper 820, p. 45-50.

Miller, W.R., Motooka, J.M., and Hugh, J.B., 1985a, Maps showing distribution of bismuth in heavy-mineral concentrates, Richfield $1^{\circ} \times 2^{\circ}$ quadrangle, Utah: U.S. Geological Survey Miscellaneous Field Studies Map MF-1246-E, scale 1:500,000.

$1985 \mathrm{~b}$, Maps showing distribution of lead in heavymineral concentrates, Richfield $1^{\circ} \times 2^{\circ}$ quadrangle, Utah: U.S. Geological Survey Miscellaneous Field Studies Map MF-1246-G, scale 1:500,000.

1985c, Maps showing distribution of tungsten in heavymineral concentrates, Richfield $1^{\circ} \times 2^{\circ}$ quadrangle, Utah: U.S. Geological Survey Miscellaneous Field Studies Map MF-1246-K, scale 1:500,000.

Mitchell, G.C., 1979, Stratigraphy and regional implications of the Argonaut Energy No. 1 Federal, Millard County, Utah, in Newman, G.F., and Goode, H.D., eds., Basin and Range symposium and Great Basin field conference: Denver, Colo,, Rocky Mountain Association of Geologists and Utah Geological Association, p. 503-514.
Molenaar, C.M., and Sandberg, C.A., 1983, Petroleum potential of wilderness lands in Utah, in Miller, B.M., ed., Petroleum potential of wilderness lands in the western United States: U.S. Geological Survey Circular 902-A-P, p. K1-K14.

Morris, H.T., 1986, Descriptive model of polymetallic replacement deposits, in Cox, D.P., and Singer, D.A., eds., Mineral deposit models: U.S. Geological Survey Bulletin 1693, p. 99-100.

Powers, R.B., 1983, Petroleum potential of wilderness lands in Wyoming-Utah-Idaho thrust belt, in Miller, B.M., ed., Petroleum potential of wilderness lands in the western United States: U.S. Geological Survey Circular 902-A-P, p. N1-N14.

Rowley, P.D., Steven, T.A., Anderson, J.J., and Cunningham, C.G., 1979, Cenozoic stratigraphic and structural framework of southwestern Utah: U.S. Geological Survey Professional Paper 1149, 22 p.

Steven, T.A., and Morris, H.T., 1984, Mineral resource potential of the Richfield $1^{\circ} \times 2^{\circ}$ quadrangle, west-central Utah: U.S. Geological Survey Open-File Report 84-521, $53 \mathrm{p}$.

1987, Summary mineral resource appraisal of the Richfield $1^{\circ} \times 2^{\circ}$ quadrangle, west-central Utah: U.S. Geological Survey Circular 916, 24 p.

U.S. Bureau of Mines and U.S. Geological Survey, 1980, Principles of a resource/reserve classification for minerals: U.S. Geological Survey Circular 831, 5 p.

U.S. Department of Energy, 1979, Aerial radiometric and magnetic survey, Richfield national topographic map, Utah: Report GJBX-172 (79). Available from Books and Open-File Reports Section, U.S. Geological Survey, Federal Center, Box 25425, Denver, CO 80225.

U.S. Geological Survey, 1972a, Aeromagnetic map of parts of the Delta and Richfield $1^{\circ} \times 2^{\circ}$ quadrangles, Utah: U.S. Geological Survey Open-File Report 72-385, scale 1:250,000.

1972b, Aeromagnetic map of parts of the Richfield and Cedar City $1^{\circ} \times 2^{\circ}$ quadrangles, Utah: U.S. Geological Survey Open-File Report 72-387, scale 1:250,000.

Whelan, J.A., 1982, Geology, ore deposits, and mineralogy of the Rocky Range, Utah: Utah Geological and Mineral Survey Special Studies, no. 57, 35 p.

Zietz, Isidore, Shuey, Ralph, and Kirby, J.R., Jr., 1976, Aeromagnetic map of Utah: U.S. Geological Survey Geophysical Investigations Map GP-907, scale 1:1,000,000. 

APPENDIX 


\title{
DEFINITION OF LEVELS OF MINERAL RESOURCE POTENTIAL AND CERTAINTY OF ASSESSMENT
}

\author{
Definitions of Mineral Resource Potential
}

LOW mineral resource potential is assigned to areas where geologic, geochemical, and geophysical characteristics define a geologic environment in which the existence of resources is unlikely. This broad category embraces areas with dispersed but insignificantly mineralized rock as well as areas with few or no indications of having been mineralized.

MODERATE mineral resource potential is assigned to areas where geologic, geochemical, and geophysical characteristics indicate a geologic environment favorable for resource occurrence, where interpretations of data indicate a reasonable likelihood of resource accumulation, and (or) where an application of mineral-deposit models indicates favorable ground for the specified type(s) of deposits.

HIGH mineral resource potential is assigned to areas where geologic, geochemical, and geophysical characteristics indicate a geologic environment favorable for resource occurrence, where interpretations of data indicate a high degree of likelihood for resource accumulation, where data support mineral-deposit models indicating presence of resources, and where evidence indicates that mineral concentration has taken place. Assignment of high resource potential to an area requires some positive knowledge that mineral-forming processes have been active in at least part of the area.

UNKNOWN mineral resource potential is assigned to areas where information is inadequate to assign low, moderate, or high levels of resource potential.

NO mineral resource potential is a category reserved for a specific type of resource in a well-defined area.

\section{Levels of Certainty}

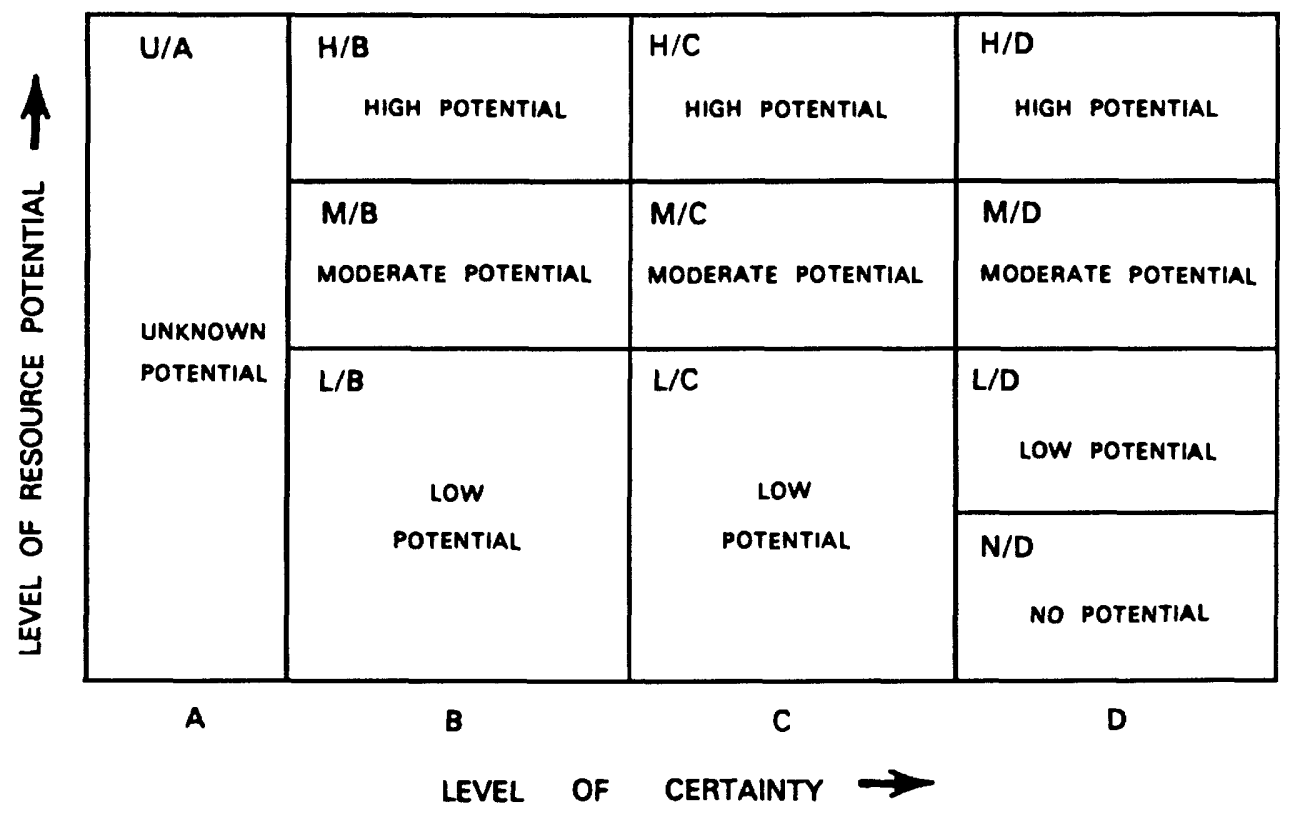

A. Available information is not adequate for determination of the level of mineral resource potential

B. Available information suggests the level of mineral resource potential.

C. Available information gives a good indication of the level of mineral resource potential.

D. Available information clearly defines the level of mineral resource potential.

\section{Abstracted with minor modifications from:}

Taylor, R. B., and Steven, T. A., 1983, Definition of mineral resource potential: Economic Geology, v. 78, no. 6, p. $1268-1270$.

Taylor, R. B., Stoneman, R. J., and Marsh, S. P., 1984, An assessment of the mineral resource potential of the San Isabel National Forest, south-central Colorado: U.S. Geological Survey Bulletin 1638, p. $40-42$.

Goudarzi, G. H., compiler, 1984, Guide to preparation of mineral survey reports on public lands: U.S. Geological Survey Open-File Report 84-0787, p. 7, 8. 
RESOURCE/RESERVE CLASSIFICATION

\begin{tabular}{|c|c|c|c|c|c|}
\hline & \multicolumn{3}{|c|}{ IDENTIFIED RESOURCES } & \multirow{2}{*}{\multicolumn{2}{|c|}{$\frac{\text { UNDISCOVERED RESOURCES }}{\text { Probability Range }}$}} \\
\hline & \multicolumn{2}{|c|}{ Demonstrated } & \multirow{2}{*}{ Inferred } & & \\
\hline & Measured & Indicated & & Hypothetical & Speculative \\
\hline ECONOMIC & Res & & Inferred Reserves & & \\
\hline $\begin{array}{l}\text { MARGINALLY } \\
\text { ECONOMIC }\end{array}$ & Margina & Reserves & $\begin{array}{c}\text { Inferred } \\
\text { Marginal Reserves }\end{array}$ & & \\
\hline $\begin{array}{l}\text { SUB- } \\
\text { ECONOMIC }\end{array}$ & $\begin{array}{r}\text { Demo } \\
\text { Subeconon }\end{array}$ & $\begin{array}{l}\text { Resources } \\
\text { Resour }\end{array}$ & $\begin{array}{c}\text { Inferred } \\
\text { Subeconomic } \\
\text { Resources }\end{array}$ & & \\
\hline
\end{tabular}

Major elements of minerel resource classification, excluding reserve base and inferred reserve bese. Modified from McKelvey, 1972, Mineral resource estimates and public policy: American Scientist, v.60, p.32-40, and U.S. Bureau of Mines and U.S. Geological Survey, 1980, Principles of a resource/reserve classification for minerals: U.5. Geological Survey Circular 831, p.5. 
GEOLOGIC TIME CHART

Terms and boundary ages used in this report

\begin{tabular}{|c|c|c|c|c|c|}
\hline EON & ERA & \multicolumn{2}{|c|}{ PERIOD } & $\mathrm{EPOCH}$ & $\begin{array}{l}\text { BOUNDARY AGE } \\
\text { IN } \\
\text { MILLION YEARS }\end{array}$ \\
\hline \multirow{17}{*}{ Phanerozoic } & \multirow{7}{*}{ Cenozoic } & \multirow{2}{*}{\multicolumn{2}{|c|}{ Quaternary }} & Holocene & 0010 \\
\hline & & & & Pleistocene & -0.010 \\
\hline & & \multirow{5}{*}{ Tertiary } & \multirow{2}{*}{$\begin{array}{l}\text { Neogene } \\
\text { Subperiod }\end{array}$} & Pliocene & \\
\hline & & & & Miocene & \\
\hline & & & \multirow{3}{*}{$\begin{array}{l}\text { Paleogene } \\
\text { Subperiod }\end{array}$} & Oligocene & $z_{2}$ \\
\hline & & & & Eocene & \\
\hline & & & & Paleocene & \\
\hline & \multirow{3}{*}{ Mesozoic } & \multicolumn{2}{|c|}{ Cretaceous } & $\begin{array}{l}\text { Late } \\
\text { Early }\end{array}$ & -96 \\
\hline & & \multicolumn{2}{|c|}{ Jurassic } & $\begin{array}{l}\text { Late } \\
\text { Middle } \\
\text { Eerly }\end{array}$ & -138 \\
\hline & & \multicolumn{2}{|c|}{ Triassic } & $\begin{array}{c}\text { Late } \\
\text { Middle } \\
\text { Early }\end{array}$ & 205 \\
\hline & \multirow{7}{*}{ Paleozoic } & \multicolumn{2}{|c|}{ Permian } & $\begin{array}{l}\text { Late } \\
\text { Early }\end{array}$ & \\
\hline & & \multirow{2}{*}{$\begin{array}{c}\text { Carboniferous } \\
\text { Periods }\end{array}$} & Pennsylvanian & $\begin{array}{l}\text { Late } \\
\text { Middle } \\
\text { Early }\end{array}$ & $2 \pi 0$ \\
\hline & & & Mississippian & $\begin{array}{l}\text { Late } \\
\text { Early }\end{array}$ & \\
\hline & & \multicolumn{2}{|c|}{ Devonian } & $\begin{array}{l}\text { Late } \\
\text { Middle } \\
\text { Early }\end{array}$ & \\
\hline & & \multicolumn{2}{|c|}{ Silurian } & $\begin{array}{l}\text { Late } \\
\text { Middle } \\
\text { Early }\end{array}$ & 4.40 \\
\hline & & \multicolumn{2}{|c|}{ Ordovician } & $\begin{array}{l}\text { Late } \\
\text { Middle } \\
\text { Early }\end{array}$ & 430 \\
\hline & & \multicolumn{2}{|c|}{ Cambrian } & $\begin{array}{l}\text { Late } \\
\text { Middle } \\
\text { Early }\end{array}$ & 300 \\
\hline \multirow{3}{*}{ Proterozoic } & Late Proterozoic & & & & (n) \\
\hline & Middle Proterozoic & & & & \\
\hline & Early Proterozoic & & & & \\
\hline \multirow{3}{*}{ Archean } & Late Archean & & & & 500 \\
\hline & Middle Archean & & & & 3000 \\
\hline & Early Archean & & & & \\
\hline
\end{tabular}

' Rocks older than 570 m.y. also called Precambrian, a time term without specific rank.

2 Informal time term without specific rank. 